\title{
BIOPROSPECTING CELLULOLYTIC FUNGI ASSOCIATED WITH TEXTILE WASTE AND INVITRO OPTIMIZATION OF CELLULASE PRODUCTION BY Aspergillus flavus NFCCI-4154
}

\author{
Priya Sutaoney $^{1, *}$, Rachana Choudhary ${ }^{2}$ and A.K. Gupta ${ }^{1}$ \\ ${ }^{1}$ Microbiology Research Laboratory, SoS in Life Science, Pt. Ravishankar Shukla University, \\ Raipur-492010 (Chhattisgarh), India \\ ${ }^{2}$ Department of Microbiology, Shri Shankaracharya Mahavidyalaya, Junwani, \\ Durg-490005 (Chhattisgarh), India \\ *E-mail: priyasut24@gmail.com
}

\begin{abstract}
This study aimed to explore the diversity as well as cellulolytic ability of fungal isolates inhabiting textile waste. Out of 88 fungal cultures isolated seasonally from nine samples of three site-s which included waste threads, 11 genera were identified viz., Aspergillus, Chaetomium, Cladosporium, Curvularia, Fusarium, Humicola, Mucor, Penicillium, Phoma, Rhizopus, Trichoderma, and Mycelia sterilia. Aspergillus was found to be the most dominant genera in all three seasons. Cellulase producing potential of fungal isolates was detected by qualitative and quantitative estimation of enzyme using carboxy methyl cellulose as a substrate. Aspergillus flavus (RTM 3) Spere NFCCI-4154 [Gene bank accession number MK036350], exhibited the highest cellulase activity and was subjected to different physical and nutritional parameters to draw out optimal conditions for enhanced CMCase production. Physical parameters for optimum CMCase recovery were identified on the $8^{\text {th }}$ day of incubation period with, $28^{\circ} \mathrm{C}$ incubation temperature at $\mathrm{pH} 5.50$, the inoculum of five mycelial disc of $10 \mathrm{~mm}$ diameter and agitation at $100 \mathrm{rpm}$ influenced the production significantly. However, it was evident from the results, that ammonium chloride $(0.3 \%)$ was the major nitrogen source, 1.5\% CMC was prime substrate and avicel (2\%) along with $0.04 \%$ sodium deoxycholate was observed to be major supplementary carbon source and additive under submerged fermentation. This study enhanced CMCase production by 2.88 fold when compared to the control.

Keywords: Aspergillus, Fungal Diversity, CMCase, Submerged Fermentation, Textile
\end{abstract}

(C) RASĀYAN. All rights reserved

\section{INTRODUCTION}

In the past few years, textile waste management and its disposal have escalated worldwide apprehensions. Textile waste includes waste produced by industries and from human consumption. These wastes are usually dumped as non-compostable waste in the environment and are collected in waste stations for land filling and incineration. ${ }^{1}$ Increasing population and living standards have raised energy demands in the society, hence biofuel production from low-cost substrates have become an imperative issue. As a substitute for fossil fuel and lignocellulosic biomass, textile waste contributes 30-45\% of cellulose which can be used as a possible raw stock for the production of biofuels. ${ }^{2}$ The crucial parameter is conversion of cellulosic feedstock into fermentable sugars, which is achieved by collaborative action of three enzymes endoglucanase [E.C.3.2.1.4], exoglucanases [E.C.3.2.1.91] and $\beta$-glucosidase [E.C.3.2.1.21] together termed as cellulases. Among these endoglucanase acts randomly on cellulose chains; exoglucanase reacts with reducing and non-reducing ends of cellulose and produces cellobiose and $\beta$-glucosidase acts on cellobiose to produce glucose. These enzymes are part of glycosyl hydrolases family responsible for hydrolyzing $\beta-1 ., 4$ glycosidic bonds present in polysaccharides. ${ }^{3-6}$

Cellulases are the third major class of enzymes having a wide range of industrial applications. These are extracellular enzymes produced in large quantities hence, they are economically important. The biotechnology of cellulases is phenomenal and capturing global recognition. Currently, cellulases are used in industries like textile and laundry, paper and pulp, brewery, wine, food and feed besides research and Rasayan J. Chem., 13(1), 64-84(2020) http://dx.doi.org/10.31788/RJC.2020.1315536

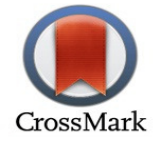


development. Researchers have also reported cellulases in the production of plant or fungal protoplast, bio-control of plant pathogens, seed germination and flowering. ${ }^{7.8}$ Cellulase encoding genes are distributed with different microbial groups. Cellulolytic enzyme systems of various life forms including protozoans, bacteria, actinomycetes, fungi, plants and nematodes have been isolated and studied. However, fungal cellulases have been a matter of attraction because they are non-aggregating, less complex and extracellular in nature. ${ }^{9}$ Cellulolytic enzymes of filamentous ascomycete Trichoderma reese $i$, have received a lot of attention, however, they lack sufficient $\beta$-glucosidase activity. Besides this, numbers of investigations are available in the literature reporting Aspergillus nidulans ${ }^{10}$, A. sydowii $^{11}, A$. hortai ${ }^{9}$, Penicillium $\mathrm{sp}^{12}$, A. terrus $^{13}$ as efficient producers of cellulases.

The exploration of potential cellulolytic organisms for effective bioconversion process as well as improvement in cellulase production has been a matter for great zeal and interest amongst researchers. Besides biochemical and molecular characterization, the production of cellulases is very much affected by both physical and nutritional factors. Hence, optimization of these parameters would result in efficient production of the enzyme. To contribute in the improvement of cellulase production this study aimed to isolate, identify and screen fungal communities residing on cellulosic textile waste and optimize culture condition for extracellular carboxy methyl cellulase (CMCase) production by potent A. flavus, which can be further exploited for degradation of textile waste and can be used by textile industries for biopolishing of textiles as well as recycling of textile waste.

\section{EXPERIMENTAL}

\section{Materials and Methods}

\section{Sampling Site}

The sampling of waste thread material was carried out in three different seasons viz. rainy, winter and summer from small scale handloom industries of Raipur, Durg and Chhuikhadan cities of the Indian state, Chhattisgarh (Table-1, Figure 1). The samples were collected in July 2015, January and May 2016. The climate of Chhattisgarh is tropical. The area has distinct dry and arid summers from March to May, cool winters from October end to January and the occurrence of rainfall is observed from June end to September. The degrading thread samples were collected in sterile plastic bags and were stored in the refrigerator at $4^{\circ} \mathrm{C}$, till isolation.

Table -1: Seasonal Isolation of Fungal Species from Cellulosic Textile Waste in Three Different Seasons from Three Site-s

\begin{tabular}{|c|c|c|c|c|c|}
\hline Sites & Description & Region & Source & Season & No. of Isolates \\
\hline \multirow[t]{3}{*}{1} & \multirow{3}{*}{$\begin{array}{c}21.2514^{\circ} \\
\mathrm{N} \\
81.6296^{\circ} \mathrm{E}\end{array}$} & \multirow[t]{3}{*}{ Raipur } & \multirow[t]{3}{*}{ Thread waste } & $\mathrm{R}$ & 22 \\
\hline & & & & $\mathrm{W}$ & 17 \\
\hline & & & & $\mathrm{S}$ & 2 \\
\hline \multirow[t]{3}{*}{2} & \multirow{3}{*}{$\begin{array}{c}21.1904^{\circ} \\
\mathrm{N} \\
81.2849^{\circ} \mathrm{E}\end{array}$} & \multirow[t]{3}{*}{ Durg } & \multirow[t]{3}{*}{ Thread waste } & $\mathrm{R}$ & 13 \\
\hline & & & & $\mathrm{W}$ & 9 \\
\hline & & & & $\mathrm{S}$ & 4 \\
\hline \multirow[t]{3}{*}{3} & \multirow{3}{*}{$\begin{array}{c}21.5250^{\circ} \\
\mathrm{N} \\
80.9993^{\circ} \mathrm{E}\end{array}$} & \multirow[t]{3}{*}{ Chhuikhadan } & \multirow[t]{3}{*}{ Thread waste } & $\mathrm{R}$ & 13 \\
\hline & & & & $\mathrm{W}$ & 6 \\
\hline & & & & $\mathrm{S}$ & 2 \\
\hline
\end{tabular}

R: rainy, W: winter, S: summer

\section{Isolation and Identification of Fungi from Textile Waste Threads}

Isolation of fungi was accomplished using the direct plate method; waste threads cut into small pieces were inoculated on to the agar plates. ${ }^{14}$ The media used for isolation of fungi included Czapek-Dox agar, malt extract agar, potato dextrose agar, and Sabourauds agar. After the growth was observed the fungi were further sub cultured and stored on PDA slants. Morphological observation of the fungal isolates was done by preparing wet mounts using lacto phenol cotton blue. ${ }^{15}$

\section{Screening of CMCase Producing Fungi}

Preliminary Screening by Plate Assay Method

The fungal isolates producing cellulases were selected qualitatively by plate assay method using CMC agar medium. Carboxy methyl cellulose sodium salt (CMC) derivative of cellulose was used as a 
substrate whereas Grams iodine was used for detecting the presence of fungal cellulases ${ }^{16}$. The composition for $\mathrm{CMC}$ agar included $(\mathrm{g} / \mathrm{l}) \mathrm{NaNO}_{3}: 2 \mathrm{~g} ; \mathrm{K}_{2} \mathrm{HPO}_{4}: 1 \mathrm{~g} ; \mathrm{MgSO}_{4}: 0.5 \mathrm{~g} ; \mathrm{KCl}: 0.5 \mathrm{~g}$; CMC Sodium salt: $5 \mathrm{~g}$; Peptone: $2 \mathrm{~g}$; Agar-Agar: $15 \mathrm{~g}$ and $\mathrm{pH}$ of the medium was adjusted to 5.50 . The plates were inoculated and incubated for $48 \mathrm{hrs}$ at $28^{\circ} \mathrm{C}$ and the growth of fungi was measured by the diameter of the colony. $5 \mathrm{ml}$ aliquot of Grams iodine was added to each plate. The formation of bluish-black complex with cellulose was observed after the addition of Grams iodine. Hydrolyzed cellulose formed pale halos around the fungal colony.

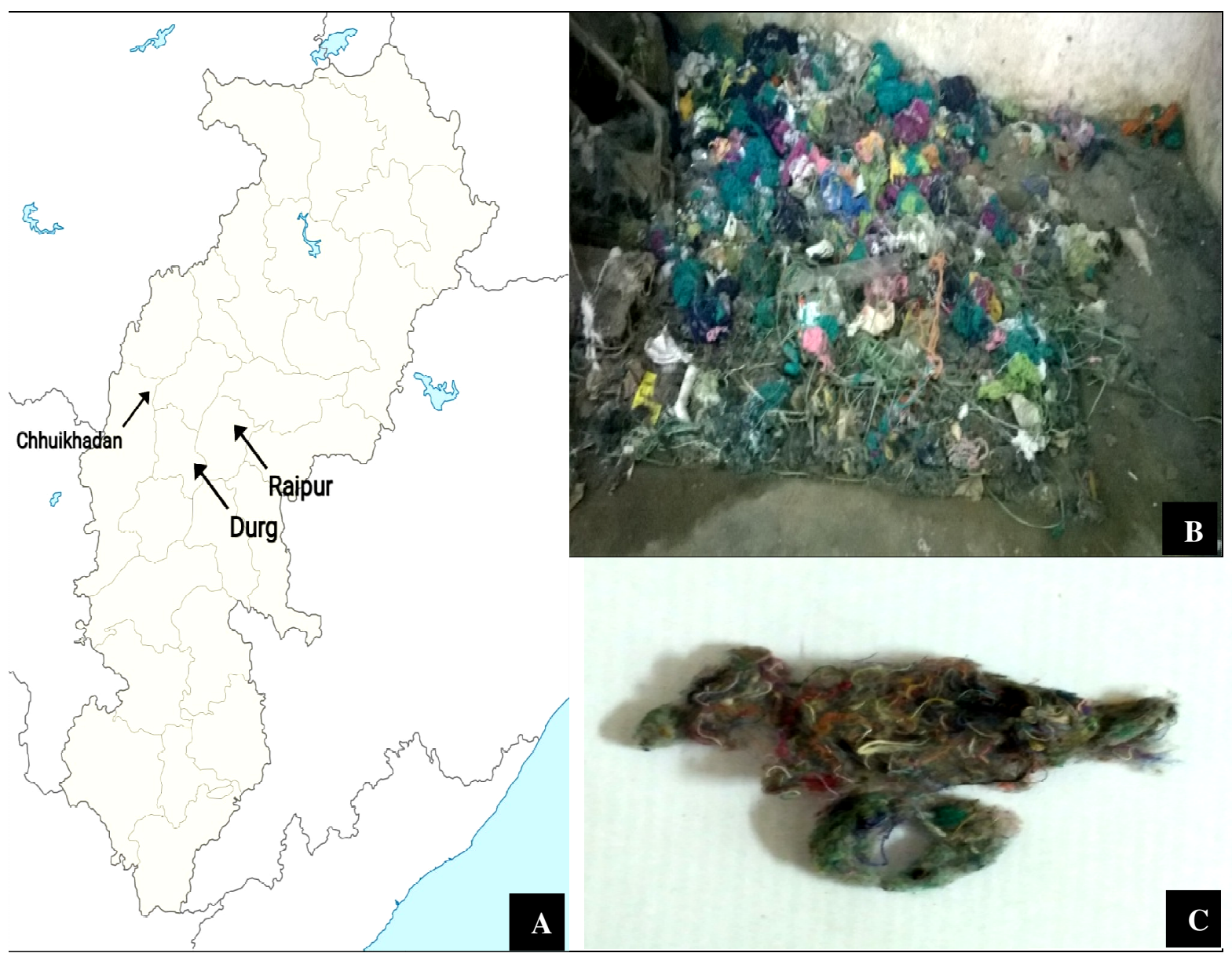

Fig.-1: (a) Outline Map of Chhattisgarh State (India) (b) Textile Waste generated by Handloom Industry of Raipur (Chhattisgarh), India; (C) Sample used for Isolation of Fungi.

The halos obtained were measured for calculating enzymatic index (EI):

$$
\mathrm{EI}=[\text { Diameter of hydrolyzed zone }] /[\text { Diameter of colony }]
$$

The fungal isolates showing EI above 1.10 were considered as potent cellulolytic fungi and were further selected for quantitative screening. ${ }^{17,18}$

\section{Production of CMCase under Submerged Fermentation and Quantitative Screening}

The production was carried out in $150 \mathrm{ml}$ Erlenmeyer flask containing $50 \mathrm{ml}$ of modified Czapek Dox medium with addition of $1 \%$ carboxy methyl cellulose sodium salt. The $\mathrm{pH}$ of the medium was adjusted to 5.50 and sterilization was carried out at $121^{\circ} \mathrm{C}$ for $15 \mathrm{~min}$, cooled and inoculated with 5 mycelial disc of $10 \mathrm{~mm}$ diameter. The flasks were kept for incubation at $28^{\circ} \mathrm{C}$ for 7 days under static conditions. The culture filtrate obtained was used for the assessment of enzymatic activity. 


\section{CMCase Assay}

The CMCase activity of culture filtrates was determined according to Wood and Bhat ${ }^{19}$ and reducing sugars were estimated using Dinitrosalicyclic acid method $\left(\right.$ Miller $\left.^{20}\right)$. The reaction mixture was prepared

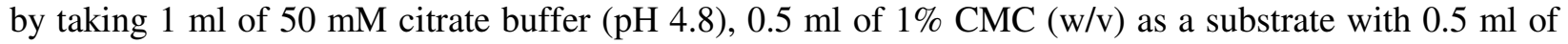
undiluted enzyme extract and incubated for $30 \mathrm{~min}$ at $50^{\circ} \mathrm{C}$, the reaction was stopped by adding $3 \mathrm{ml}$ of DNS reagent in the reaction mixture and was allowed to boil for $5 \mathrm{~min}$ until the color change was observed. Subsequently, Rochelle salt prior to cooling was added in the reaction mixture for stabilization of color. Control was prepared by the addition of $1 \mathrm{ml}$ of citrate buffer with $0.5 \mathrm{ml}$ undiluted enzyme with no substrate. The absorbance was recorded at $540 \mathrm{~nm}$. One unit of CMCase activity was defined as $1 \mu$ mole of glucose liberated per ml per min of the enzyme.

\section{Morphological and Molecular Characterization of Potent Cellulase Producing A.flavus (RTM3) Morphological Characterization}

The potent cellulolytic fungi obtained after seven days of incubation on Czapek Dox yeast extract agar, malt extract agar and potato dextrose agar was characterized on the basis of cultural and morphological characteristics. The colony characteristics included colony diameter, texture, presence of pigmentation and exudates. The fungal species were identified using a slide culture technique as well as an adhesive tape method for better recognition of conidial characteristics. The fungi were identified following Barnett and Hunter ${ }^{21}$ and Klich. ${ }^{22}$ The identification was carried out by Leica DM1000 microscope, equipped with Leica DFC 320 digital camera. Leica LAS V. 3.8.0 software was used for obtaining and analyzing the images.

\section{Molecular Characterization}

The fungal isolate (RTM 3) was identified by ITS region of ribosomal DNA nucleotide sequencing. Genomic DNA was isolated from seven days old fungal isolate grown on selective media. Polymerase chain reaction amplification of fungal rDNA was carried out using conserved primers ITS4 and ITS5. ABI-BigDye ${ }^{\circledR}$ Terminator v3.1 Cycle Sequencing Kit was employed for setting the sequencing PCR. ABI 3100 automated DNA sequencer was utilized for obtaining raw sequence which was further edited manually for inconsistency. The blast program was employed to search the homologous sequences in NCBI Gene Bank database. ITS-r DNA sequence was aligned and compared with publically available sequences using the Clustal $\mathrm{W}$ program. The phylogenetic tree was constructed by the neighbor-joining method using Mega 7 software.

\section{Optimization of Process Parameters for Enhanced CMCase Production}

The potent cellulolytic isolate was further optimized for different physical and nutritional parameters, using one factor at a time approach.

\section{Effect of Incubation Period}

Incubation plays an important role in optimum CMCase production. In this study, enzyme production was carried for 10 days and assessment was done after every 24 hours of the interval, biomass (g/ 100ml) was recorded.

\section{Effect of Temperature}

In order to analyze efficacious temperature for optimal production of $\mathrm{CMCase}$, fermentation was carried at a different temperature ranging from $25-50^{\circ} \mathrm{C}$ at an interval of $5^{\circ} \mathrm{C} .28^{\circ} \mathrm{C}$ was kept as control.

\section{Effect of $\mathbf{p H}$}

The $\mathrm{pH}$ of the growth medium is an important parameter for enhancing enzyme production. To analyze the optimal $\mathrm{pH}$, fermentation was carried out at different $\mathrm{pH}$ ranging between 4.5 and 7.5. Control experiments were performed at $\mathrm{pH}$ 5.5. 


\section{Effect of Inoculum Size}

Mycelial disc of $10 \mathrm{~mm}$ diameter with varying numbers viz. 3, 4, 5, 6, 7 and 8 discs was inoculated in the fermentation medium. Suitable inoculum size for maximum cellulase production and biomass was recorded.

\section{Effect of Agitation Rate}

Effect of agitation at different speed viz. 50-200 rpm at intervals of $50 \mathrm{rpm}$ was assessed for cellulase production. The crude was filtered and the cellulase activity was compared with the prior optimized static condition.

\section{Effect of Supplementary Nitrogen Source and Their Concentration}

Different supplementary nitrogen sources were substituted with the sodium nitrate (control) for assessment of cellulase production which included ammonium chloride, ammonium sulphate, Lasparagine, meat extract, peptone, potassium nitrate, tryptone, urea and yeast extract. The nitrogen source exhibiting maximum cellulase production was further selected and incorporated in different concentrations for assessment of higher enzyme production.

\section{Effect of Carboxy Methyl Cellulose Concentration on Cellulase Production}

Different concentrations of CMC was assessed on cellulase production viz., $0.5 \%-3 \%(0.5,1.0,1.5,2.0$, 2.5, and 3.0) and compared with control (1\%).

\section{Effect of Supplementary Carbon Source and Their Concentration}

Different supplementary carbon sources were incorporated along with the initially optimized substrate concentration for assessment of cellulase production which included avicel, cellobiose, fructose, glucose, inulin, inositol, maltose, starch, sucrose and sorbitol. The carbon source exhibiting maximum cellulase production was further selected and incorporated in different concentrations for assessment of higher enzyme production.

\section{Effect of Additives and Metal Ions}

Different additives and metal ions were incorporated in order to attain maximum cellulase production viz., cobalt chloride, clove oil, manganese chloride, nicotinic acid, pyridoxine, sodium deoxycholate, thiamine, Tween 20 , Tween 80 , zinc sulphate.

\section{Data Analysis}

Fungal diversity was evaluated using PAST statistical software. Margalef index: $D=(S-1) / \ln N(S=$ number of genus, $\mathrm{N}=$ total number of individuals), Shannon Wiener index: $\mathrm{H}=\sum\left[\left(\mathrm{p}_{i}\right) \mathrm{x} \ln \left(\mathrm{p}_{i}\right)\right](\mathrm{p}=$ proportion of particular species $(\mathrm{p}=\mathrm{ni} / \mathrm{N}), \mathrm{n}=$ number of individuals of each genus, $\mathrm{N}=$ total number of organisms from all the genus) Simpson's diversity index (1-D): $\sum n(n-1) / N(N-1)$ ( $n=$ total number of organisms of particular genus, $\mathrm{N}=$ total number of organisms from all the genus). Means of data and standard error were calculated using the data analysis tool of Microsoft Excel. One way analysis of variance was performed with SPSS (16.0) software. A post hoc Duncan's multiple range tests were performed to analyze the significant differences within the variables.

\section{RESULTS AND DISCUSSION}

In this investigation, fungi were isolated from three textile waste dumping site-s and explored for the mycoflora associated with cellulosic textile materials (Figure 1). The cellulolytic potential of inhabiting fungi was also analyzed. Isolation was carried out in different seasons and media so that diverse classes of fungi can be obtained. A total of 88 fungal cultures were isolated from nine samples, which included waste threads. 78 fungal isolates belonged to mitosporic fungi (Anamorphic ascomycetes), 5 fungal isolates belonged to Zygomycetes, whereas 5 fungal cultures isolated were dematitious sterile mycelia (lacking spores). A total of 11 genera were identified viz., Aspergillus, Chaetomium, Cladosporium, Curvularia, Fusarium, Humicola, Mucor, Penicillium, Phoma, Rhizopus and Trichoderma. Aspergillus 


\section{RASĀYAN J. Chem.}

Vol. 13 | No. 1 |64 - 84| January - March | 2020

(54.54\%) was found to be dominating genera in all the samples isolated whereas Chaetomium, Phoma and Rhizopus were lowest having $1.13 \%$ occurrences (Table-2). The findings were similar to Algarni et al. ${ }^{14}$ and Kavkler et al. ${ }^{23}$ respectively, who reported the presence of Alternaria alternata, Aspergillus flavus, A. fumigatus, Fusarium chrysogenum, Rhizopus nigricans and Trichoderma viridae from warehouse fabrics in Saudi Arabia and Aspergillus clavatus, A. proliferans, Cladosporium sp. and Penicillium coryophilum from the historical textiles of the Slovene museum.

Table - 2: Frequency and Percent Occurrence of Fungal Isolates from the Three Site-s

\begin{tabular}{c|l|c|c|c|c|c|c|c|c|c|c}
\hline S. N. & \multicolumn{1}{|c|}{ Fungal Isolates } & \multicolumn{3}{c|}{ Site- } & \multicolumn{3}{c|}{ Site- } & \multicolumn{3}{c}{ Site- 3 } & $\%$ \\
\hline & & $\mathrm{R}$ & $\mathrm{W}$ & $\mathrm{S}$ & $\mathrm{R}$ & $\mathrm{W}$ & $\mathrm{S}$ & $\mathrm{R}$ & $\mathrm{W}$ & $\mathrm{S}$ & \\
\hline 1. & Aspergillus & 15 & 8 & 2 & 6 & 6 & 3 & 6 & 1 & 1 & 54.54 \\
\hline 2. & Chaetomium & - & - & - & - & - & - & 1 & - & - & 1.13 \\
\hline 3. & Cladosporium & 1 & - & - & 2 & - & - & - & - & - & 3.40 \\
\hline 4. & Curvularia & - & 5 & - & 1 & - & - & 5 & - & - & 12.50 \\
\hline 5. & Fusarium & 2 & - & - & 1 & - & - & - & - & - & 3.40 \\
\hline 6. & Humicola & 2 & 2 & - & - & 2 & - & - & 1 & - & 7.95 \\
\hline 7. & Mucor & - & - & - & - & - & - & 1 & 2 & 1 & 4.54 \\
\hline 8. & Penicillium & - & - & - & 2 & & - & - & - & - & 2.27 \\
\hline 9. & Phoma & - & - & - & - & - & 1 & - & - & - & 1.13 \\
\hline 10. & Rhizopus & - & - & - & - & - & - & - & 1 & - & 1.13 \\
\hline 11. & Trichoderma & 1 & - & - & - & 1 & - & - & - & - & 2.27 \\
\hline 12. & Mycelia sterilia & 1 & 2 & - & 1 & - & - & - & 1 & - & 5.68 \\
\hline
\end{tabular}

R: Rainy season, W: Winter season, S: Summer season, -: non occurrence of genera, Site- 1: Raipur, Site- 2: Durg, Site- 3: Chhuikhadan, \%: percent occurrence

The fungal diversity varied in all the three site-s in different seasons. The diversity was calculated using Simpson index whereas richness and abundance were calculated using Shannon-Weiner and Margalef index. The values of Simpson's index indicated that site- 3 was more diverse as compared to site-s 2 and 1. Shannon index indicated abundance and evenness more in site- 3 and Margalef index indicated higher richness in site-2 (Table-3).

Table-3: Diversity Indices of Fungal Entities of Textile Waste

\begin{tabular}{c|c|c|c}
\hline Diversity Indices & Site- 1 & Site- 2 & Site- 3 \\
\hline Margalef & 1.365 & 2.427 & 2.233 \\
\hline Simpson_1-D & 0.5549 & 0.6639 & 0.7750 \\
\hline Shannon_H & 1.167 & 1.586 & 1.712 \\
\hline
\end{tabular}

A total of 16 fungal isolates were found to have cellulolytic potential with enzymatic index ranging from 1.12 to 2.13. Figure-2 represents the photographs of colonial and morphological characteristics of fungal isolates including their primary cellulase activity. Pale halos were visible in a plate containing CMC when treated with Grams iodine. This suggested that fungi were able to digest cellulose. These results were similar to Herculano et al. ${ }^{24}$ who isolated cellulolytic fungi from castor waste. These fungal isolates were further subjected to enzymatic production by submerged fermentation incorporating carboxy methyl cellulose as a substrate after 7 days of incubation. The highest carboxy methyl cellulase activity was exhibited by Aspergillus flavus Spere. NFCCI-4154 where as the lowest activity was exhibited by Curvularia sp (Table-4). These results were in agreement with Jahangeer et al. ${ }^{25}$, who performed CMCase assay and reported the highest activity by $A$. niger $(0.193 \mathrm{U} / \mathrm{ml})$ followed by $A$. nidulans $(0.160 \mathrm{U} / \mathrm{ml})$ and low levels of activity by A. flavus and Penicillium sp. $(0.060 \mathrm{U} / \mathrm{ml}$ and $0.045 \mathrm{U} / \mathrm{ml}$ respectively). 
RASĀYAN J. Chem.

Vol. 13 | No. 1 |64 - 84| January - March | 2020

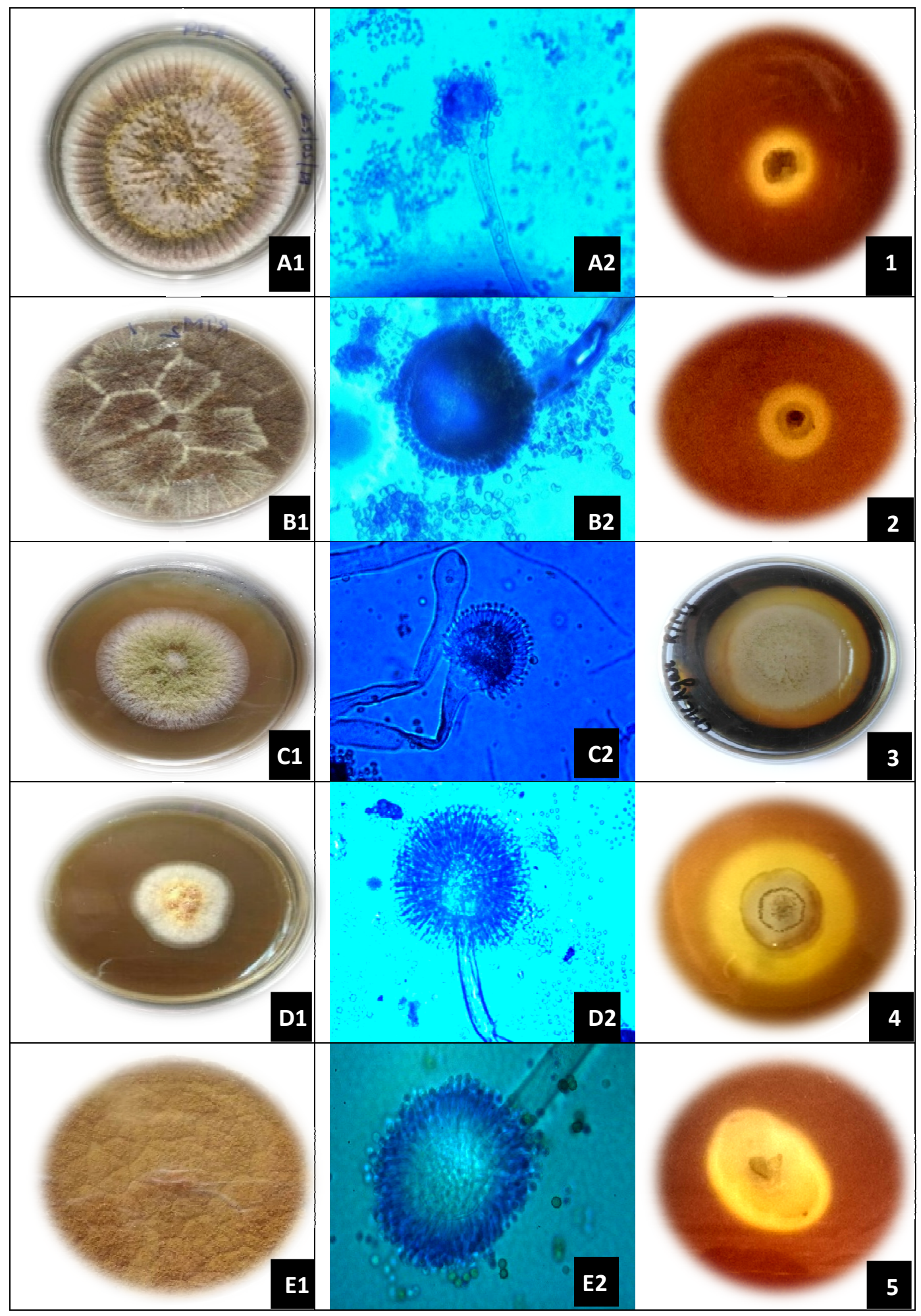


RASĀYAN J. Chem.

Vol. 13 | No. 1 |64 - 84| January - March | 2020

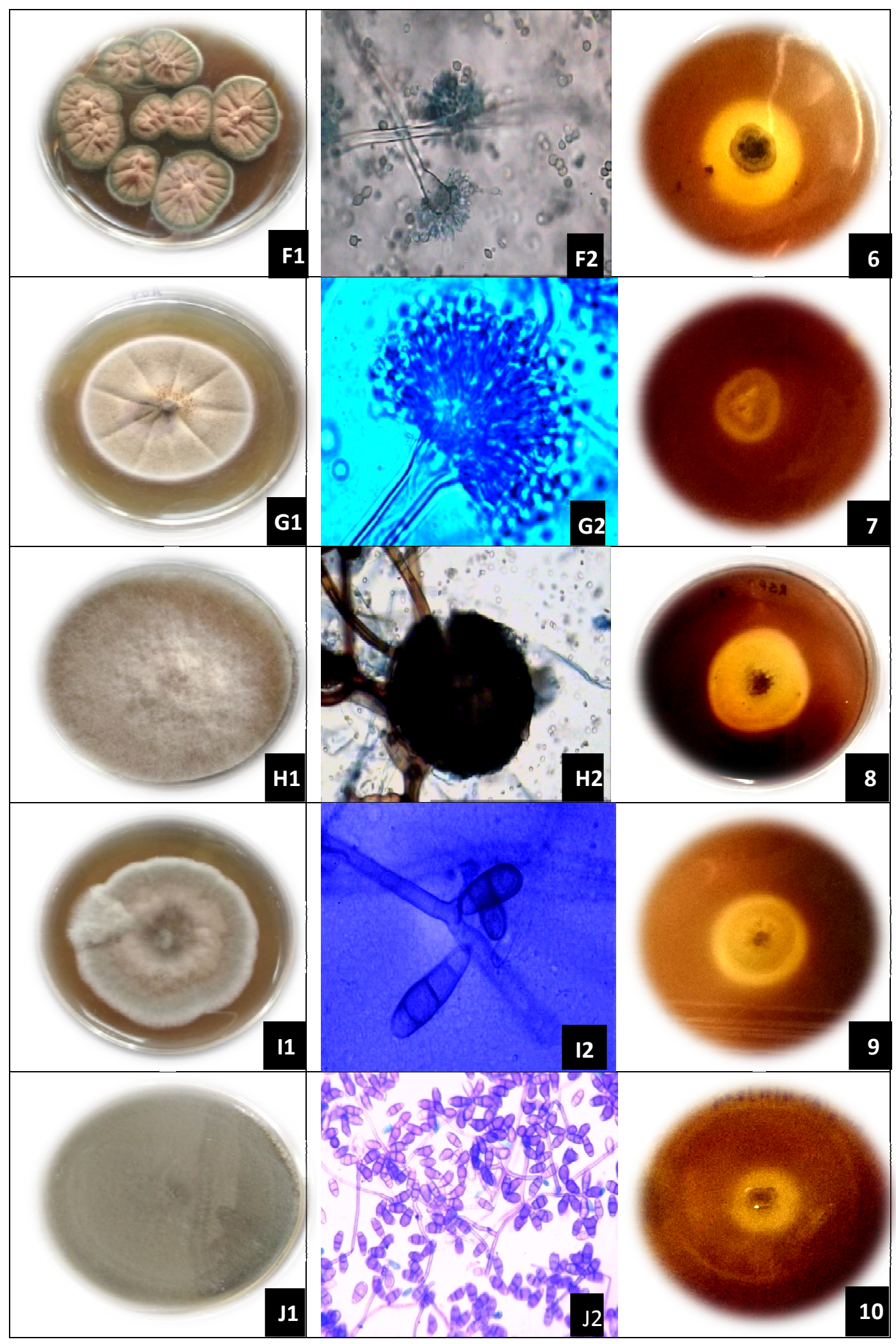


RASĀYAN J. Chem.

Vol. 13 | No. 1 |64 - 84| January - March | 2020

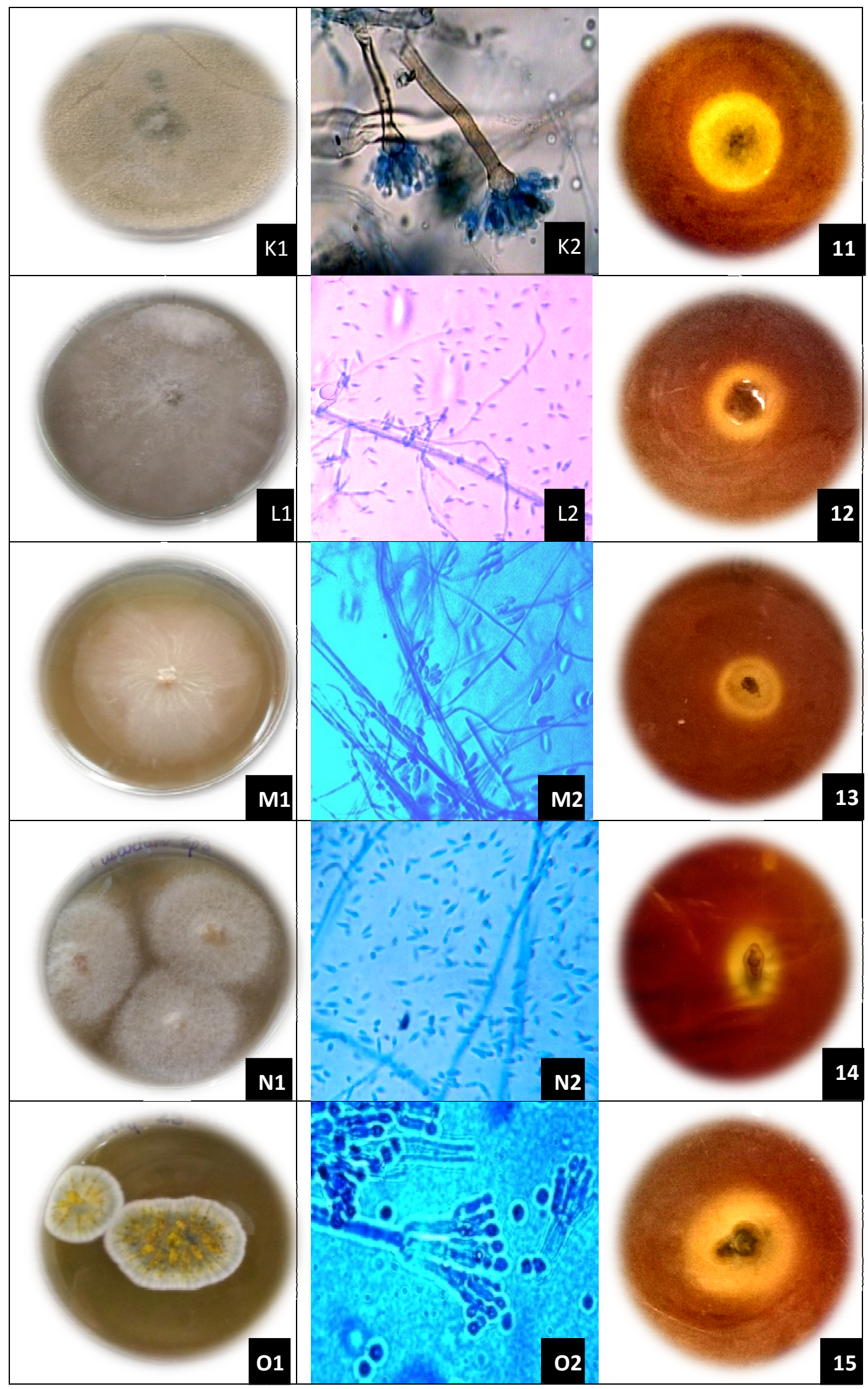


RASĀYAN J. Chem.

Vol. 13 | No. 1 |64 - 84| January - March | 2020

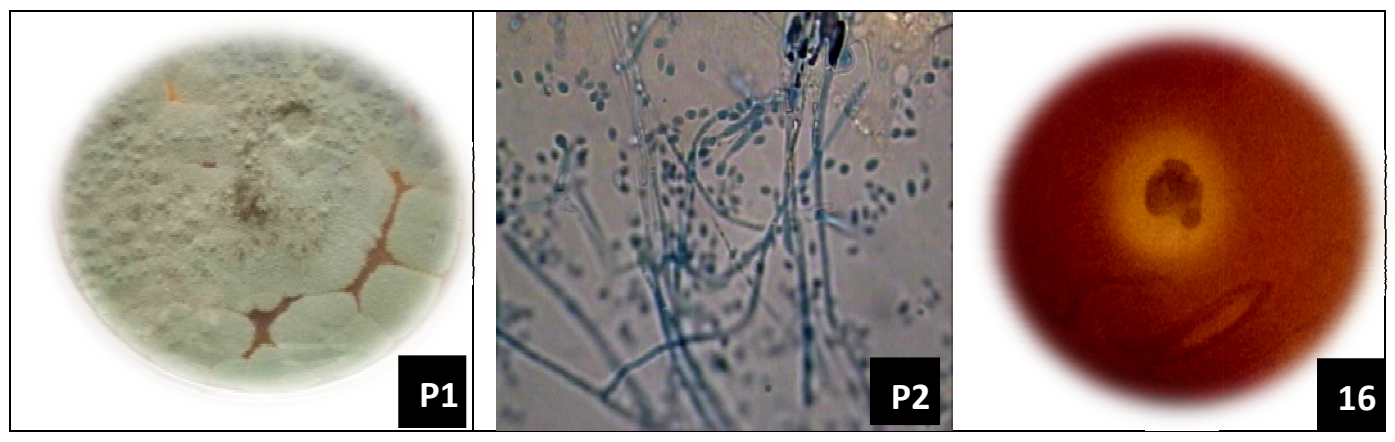

Fig.-2: A1-P1, Colonial Characteristics of Fungal Isolates, A2-P2, Microscopic Images of Fungal Isolates; 1-16,

Cellulase producing Fungi amended with CMC on Plate using Grams Iodine for Detecting Pale Halos. A1-A2:

Aspergillus allilaceous, B1-B2: A. japonicus, C1-C2: A. flavus, D1-D2: A. sclerotium, E1-E2: A. oryzae, F1-F2: A. verscicolar, G1-G2: Aspergillus sp 1, H1-H2: Rhizopus sp, I1-I2: Curvularia sp 1, J1-J2: Curvularia sp 2, K1-K2:

Emericella nidulans, L1-L2: Fusarium sp1, M1-M2: Fusarium sp 2, N1-N2: Fusarium sp 3, O1-O2: Penicillium sp 1, P1-P2: Penicillium sp 2.

Table - 4: Cellulase Activity and Enzymatic Index of Cellulolytic Fungi Isolated From Textile Waste Dumping Sites

\begin{tabular}{|c|c|c|c|c|c|c|c|}
\hline S. No. & Fungal Isolates & Code & $\varnothing c$ & $\varnothing \mathrm{h}$ & EI & $\begin{array}{c}\text { CMCase Activity } \\
\text { (IU/ ml) }\end{array}$ & $\begin{array}{c}\text { Biomass } \\
(\mathrm{g} / 100 \mathrm{ml}) \\
\end{array}$ \\
\hline 1. & $\begin{array}{l}\text { Aspergillus alliaceous } \\
\text { Thom and Church }\end{array}$ & MWCT2 & 1.56 & 2.20 & 1.41 & $0.005 \pm 0.001$ & $0.48 \pm 0.03$ \\
\hline 2. & A. japonicus Saito & RTM2 & 1.00 & 2.13 & 2.13 & $0.013 \pm 0.001$ & $0.52 \pm 0.02$ \\
\hline 3. & A. flavus Spere & RTM3 & 2.83 & 3.3 & 1.16 & $0.150 \pm 0.003$ & $0.50 \pm 0.04$ \\
\hline 4. & $\begin{array}{l}\text { A. sclerotiorum } \\
\text { Raper and Thom }\end{array}$ & RTC2 & 2.50 & 4.50 & 1.80 & $0.021 \pm 0.003$ & $0.35 \pm 0.01$ \\
\hline 5 . & $\begin{array}{l}\text { Aspergillus oryzae } \\
\text { (Ahlburg) Cohn }\end{array}$ & RTM5 & 2.00 & 3.60 & 1.80 & $0.028 \pm 0.001$ & $0.40 \pm 0.02$ \\
\hline 6. & $\begin{array}{l}\text { A. versicolar (Vuill.) } \\
\text { Tiraboschi } \\
\end{array}$ & RTC3 & 3.00 & 3.80 & 1.27 & $0.081 \pm 0.004$ & $0.49 \pm 0.03$ \\
\hline 7. & Aspergillus $\mathrm{sp} 1$ & DTS1 & 1.20 & 1.60 & 1.30 & $0.059 \pm 0.002$ & $0.50 \pm 0.04$ \\
\hline 8. & Rhizopus sp. & DTP5 & 3.50 & 4.60 & 1.31 & $0.003 \pm 0.001$ & $0.55 \pm 0.01$ \\
\hline 9. & Curvularia sp 1 & DTM2 & 2.20 & 3.00 & 1.36 & $0.009 \pm 0.003$ & $0.36 \pm 0.02$ \\
\hline 10. & Curvularia sp 2 & MWCT1 & 1.20 & 2.20 & 1.83 & $0.001 \pm 0.0002$ & $0.35 \pm 0.01$ \\
\hline 11. & $\begin{array}{l}\text { Emericella nidulans } \\
\text { Fennel \& Raper }\end{array}$ & RTM6 & 1.60 & 2.00 & 1.25 & $0.032 \pm 0.003$ & $0.45 \pm 0.03$ \\
\hline 12. & Fusarium sp1 & DTP10 & 1.60 & 2.43 & 1.51 & $0.005 \pm 0.003$ & $0.48 \pm 0.04$ \\
\hline 13. & Fusarium $\mathrm{sp} 2$ & RTM4 & 1.80 & 2.03 & 1.12 & $0.030 \pm 0.004$ & $0.50 \pm 0.02$ \\
\hline 14. & Fusarium sp 3 & MWRT5 & 1.00 & 1.80 & 1.80 & $0.008 \pm 0.001$ & $0.40 \pm 0.03$ \\
\hline 15. & Penicillium sp 1 & DTP3 & 2.10 & 4.00 & 1.90 & $0.024 \pm 0.001$ & $0.39 \pm 0.01$ \\
\hline 16. & Penicillium sp 2 & DTP4 & 1.50 & 3.00 & 2.00 & $0.011 \pm 0.001$ & $0.35 \pm 0.02$ \\
\hline
\end{tabular}

Øc: mean diameter of colony, Øh: mean diameter of zone of hydrolysis, EI: Enzymatic index

\section{Colonial and Morphological Characterization of A. flavus \\ Colonies on CYA}

Colony diameter ranging from 40-45 mm after 5 days of incubation and $65-70 \mathrm{~mm}$ after 7 days of incubation, powdery in appearance, yellowish-green in color, having white borders, pale yellow at the reverse, presence of sclerotia, becoming dark green when old lacking exudates and pigments.

\section{Colonies on PDA}

Colony diameter ranging from 40-42 $\mathrm{mm}$ after 5 days of incubation and 70-75 $\mathrm{mm}$ after 7 days incubation, olivaceous green having the powdery appearance, pale yellow at reverse possessing sulcate pattern, older culture becoming dark green, sclerotia present, exudates and pigments absent. 
RASĀYAN J. Chem.

Vol. 13 | No. 1 |64 - 84| January - March | 2020

\section{Colonies on MEA}

Colony diameter ranging from 41-43mm after 5 days of incubation and $65-70 \mathrm{~mm}$ after 7 days of incubation. Olivaceous green, floccose and powdery at front, pale yellow reverse, exudates and pigments were absent.

\section{Microscopic Characteristics}

Conidial heads radiate, columnar and split, philaides both uniseriate and biseriate ampuliform, vesicles pyriform upper half occasionally covered by metulae, pyriform vesicles ranging in diameter from 23.60 $\mu \mathrm{m}-34.55 \mu \mathrm{m}$, conidia yellowish green in color and texture of conidial walls smooth to finely rough, globose in nature ranging in diameter from 3.05-4.08 $\mu \mathrm{m}$. Conidiophores coarsely roughened.

\section{Molecular Characterization of A.flavus}

ITS-rDNA regions are highly conserved and hence are considered significant genetic marker involved in species identifications. The sequences were amplified and were subjected to sequence homology analysis. Phylogenetic analysis was carried out with 15 matches of the sequence by neighbor joining method in Molecular evolutionary genetics analysis 7.0v (MEGA7.0v). The phylogenetic relationships were obtained by comparing ITS-rDNA sequences of potent fungal isolate (RTM3) with 15 sequences obtained from NCBI-BLAST database using Clustal W of MEGA 7.0v. Phylogenetic tree of potent fungal isolate is shown in Fig.-3. The sequence of potential isolate was deposited in NCBI-Gene bank (Gene bank accession number MK036350). The isolate RTM3 was identified as A. flavus.

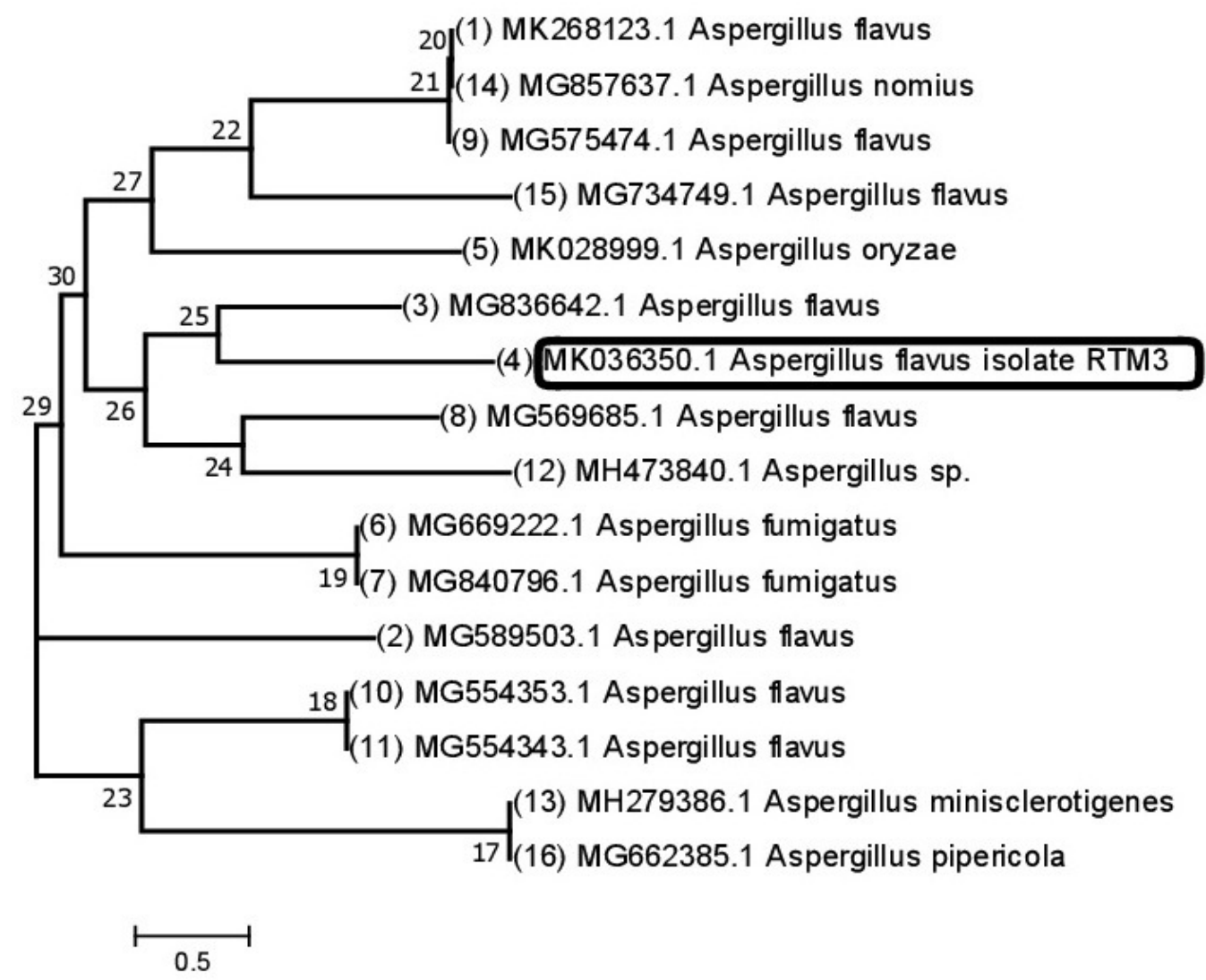

Fig.-3: The evolutionary history was inferred using the Neighbor-Joining method. ${ }^{26}$ The optimal tree with the sum of branch length $=15.14465843$ is shown. The tree is drawn to scale, with branch lengths in the same units as those of the evolutionary distances used to infer the phylogenetic tree. The evolutionary distances were computed using the Maximum Composite Likelihood method ${ }^{27}$ and are in the units of the number of base substitutions per site. The analysis involved 16 nucleotide sequences. All positions containing gaps and missing data were eliminated. There were a total of 536 positions in the final dataset. Evolutionary analyses were conducted in MEGA7. ${ }^{28}$ 


\section{Optimization of Process Parameters for Improving CMCase Production by A.flavus Effect of Incubation Period}

Optimum incubation period was assessed by inoculating Aspergillus flavus in $\mathrm{mCD}$ broth for 10 days, the samples were withdrawn after every $24 \mathrm{hrs}$; A. flavus showed highest CMCase production on $8^{\text {th }}$ day i.e. $0.164 \mathrm{IU} / \mathrm{ml}$ and declined thereafter. The biomass was $0.18 \mathrm{~g} / 100 \mathrm{ml}$ on first day and gradually increased with fermentation time and reached a peak on $6^{\text {th }}$ day of incubation $(0.50 \mathrm{~g} / 100 \mathrm{ml})$, remained stable till $7^{\text {th }}$ day and declined thereafter (Figure 4). The results of one way ANOVA followed by Duncan's test substantiate the differences in the CMCase activity at different incubation periods $(\mathrm{F}=355.653 ; \mathrm{p}<$ 0.001). Reduction in enzymic activity could be due to exhaustion of nutrients with respect to time which might create stress in fungal metabolism rendering enzyme secretion system inactive ${ }^{29}$, however, protease production in the medium and aggregation of cellobiose and glucose could also lead to an inhibitory effect on enzymic activity. ${ }^{30,31}$ This study substantiates the work of Saini et al. ${ }^{32}$ who demonstrated maximum CMCase production on $8^{\text {th }}$ day by Trichoderma reesei (NCIM 992) using Parthenium hysterophorous as biomass. However, different studies demonstrated incongruity in the optimal incubation period for maximal CMCase production due to different microbial species, cultural conditions and utilization of different substrates. Aspergillus niger and Trichoderma sp. produced optimal CMCase on $4^{\text {rth }}$ and $6^{\text {th }}$ day under submerged fermentation using cellulose as a substrate ${ }^{34}$ while A.niger showed the highest production of CMCase after $3^{\text {rd }}$ day in submerged fermentation and $4^{\text {rth }}$ day under solid-state fermentation using coir waste as substrate. ${ }^{34}$

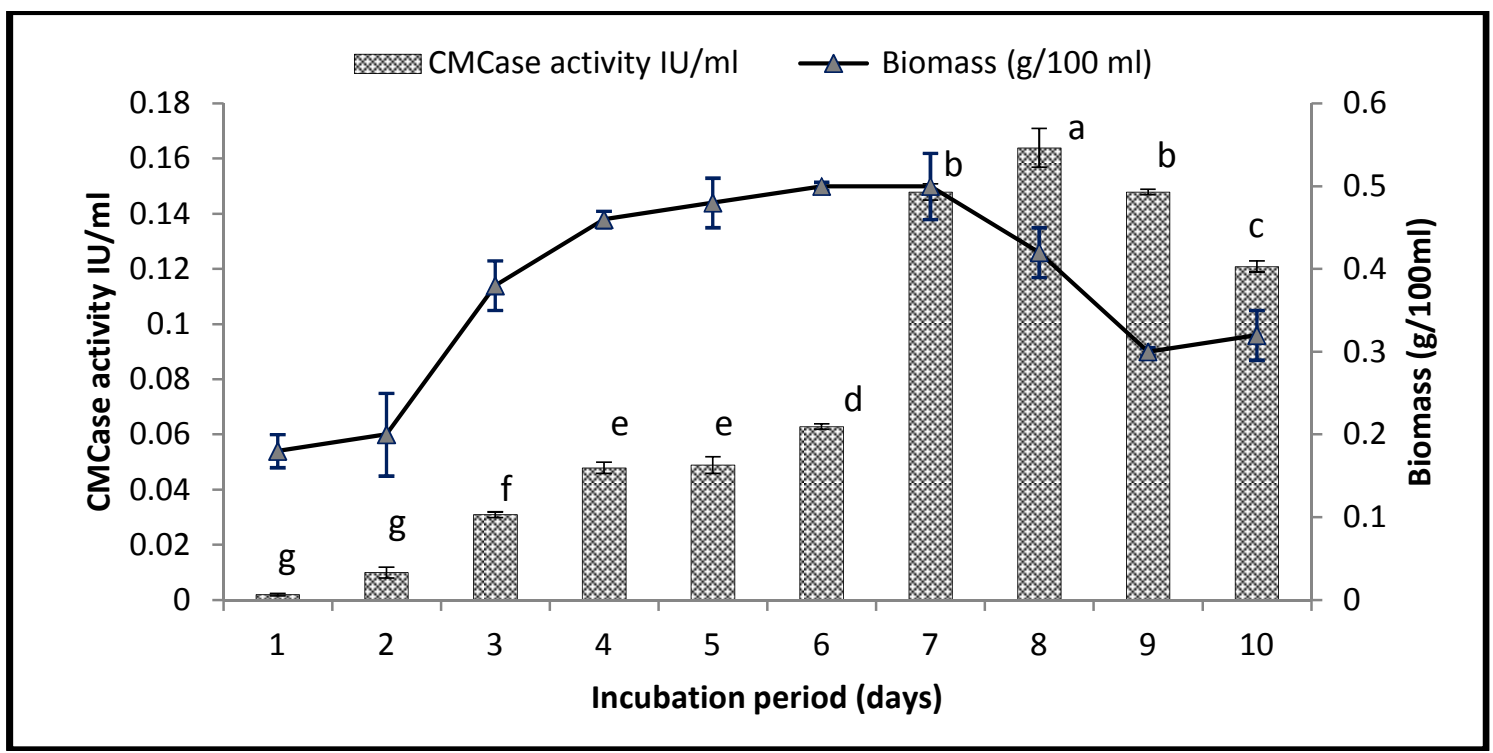

Fig.- 4: Effect of Incubation Period on Biomass and CMCase production by A. flavus. Bars with Different Alphabets exhibit statistically Significant Difference $(\mathrm{p}<0.05)$

\section{Effect of Temperature}

Temperature is a major process parameter that plays a significant role in the production of the enzyme as well as biomass. It is also known to play an important role in the secretion of the extracellular enzyme by altering the properties of the cell membrane. ${ }^{35}$ However, there could be a variation in optimum temperature when compared with fungal biomass and enzyme production. ${ }^{32}$ As shown in figure 5 the CMCase activity was found to increase between temperature ranging from $25-30^{\circ} \mathrm{C}$ with an optimal production of the enzyme at $28^{\circ} \mathrm{C}(0.178 \mathrm{IU} / \mathrm{ml})$, which declined with further increase in temperature and showed no activity above $40^{\circ} \mathrm{C}$. The one way ANOVA analysis followed by Duncan's test indicated a significant difference between the CMCase activity measured at different temperatures $(\mathrm{F}=1070.555$; $\mathrm{p}<0.001)$. However, the biomass slightly increased with the rise in temperature and reached a maximum at $30^{\circ} \mathrm{C}(0.53 \mathrm{~g} / 100 \mathrm{ml})$, remained stable at $35^{\circ} \mathrm{C}$ and declined as temperature increased. The higher temperature is assumed to denature enzyme activity and shows a negative effect on fungal biomass production. ${ }^{36}$ The results were in agreement with Chellapandi et al. ${ }^{37}$ and Ahmad et al. ${ }^{38}$ who reported 
RASĀYAN J. Chem.

Vol. 13 | No. 1 |64 - 84| January - March | 2020

maximal CMCase production with Streptomyces spp. and T. harzianum at $28^{\circ} \mathrm{C}$ respectively. Several studies indicated different incubation temperatures for optimal CMCase production due to microbial strain variation. Ali et al. ${ }^{39}$ reported optimal cellulase activity by $A$. niger $\mathrm{Z} 10$ and A. terrus at $40^{\circ} \mathrm{C}$ under SSF. However, Penicillium sp. and T. reesei (NCIM 1186) exhibited high titers of CMCase activity at $30^{\circ} \mathrm{C}^{12,4}$

\section{Effect of pH}

The initial $\mathrm{pH}$ of the growth medium is the most crucial physical parameter involved in instigating morphological variation in microorganism as well in the production of enzyme. Microbial growth is responsible for affecting the $\mathrm{pH}$ which ultimately affects the product stability of the medium. The optimal $\mathrm{pH}$ may deviate with respect to different microbial strains and enzymes. ${ }^{12}$ The present study evaluates the effect of $\mathrm{pH}$ on CMCase production by A. flavus. Figure 6 represents the maximum CMCase activity and growth was maximum at $\mathrm{pH} 5.50$ (control) i.e. $0.180 \mathrm{IU} / \mathrm{ml}$ and fungal biomass $0.60 \mathrm{~g} / 100 \mathrm{ml}$. The results of one way ANOVA and Duncan's test revealed significant differences in the CMCase activity for different $\mathrm{pH}(\mathrm{F}=2581.549 ; \mathrm{p}<0.001)$ It was also observed that the enzyme activity was stable between the $\mathrm{pH}$ range 5.0-6.0, however, the enzyme activity and fungal biomass gradually declined beyond the optimum condition.

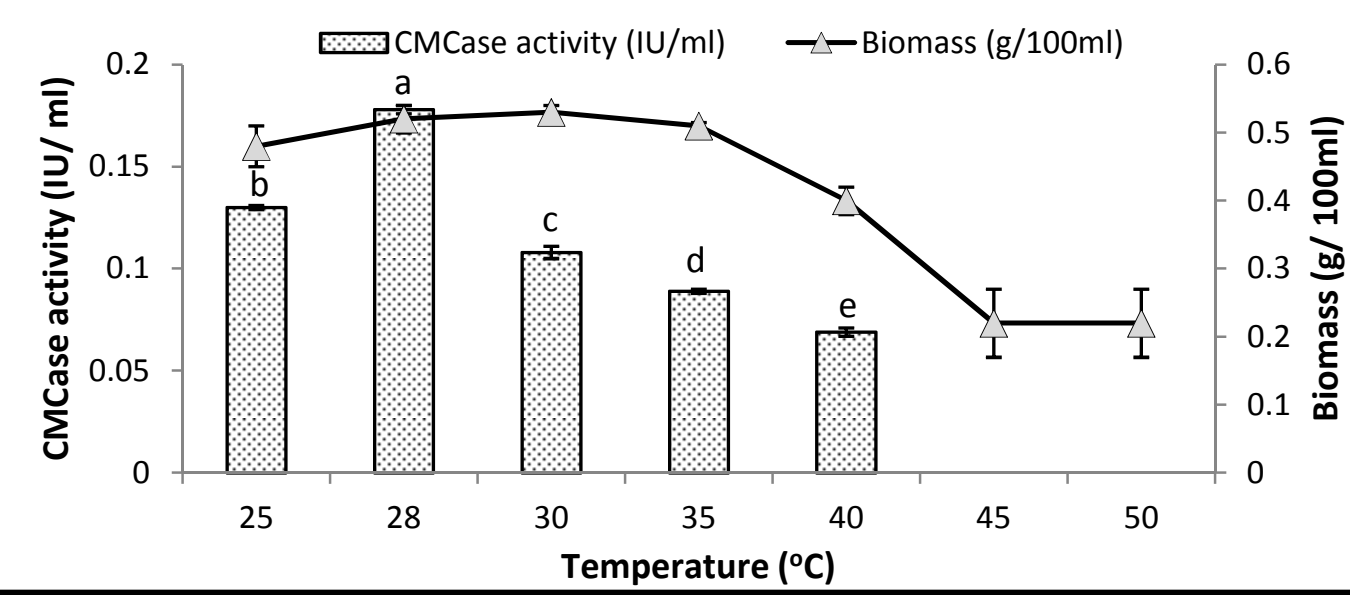

Fig.-5: Effect of Temperature on Biomass and CMCase production by A. flavus. Bars with Different Alphabets exhibit statistically Significant Difference $(\mathrm{p}<0.05)$

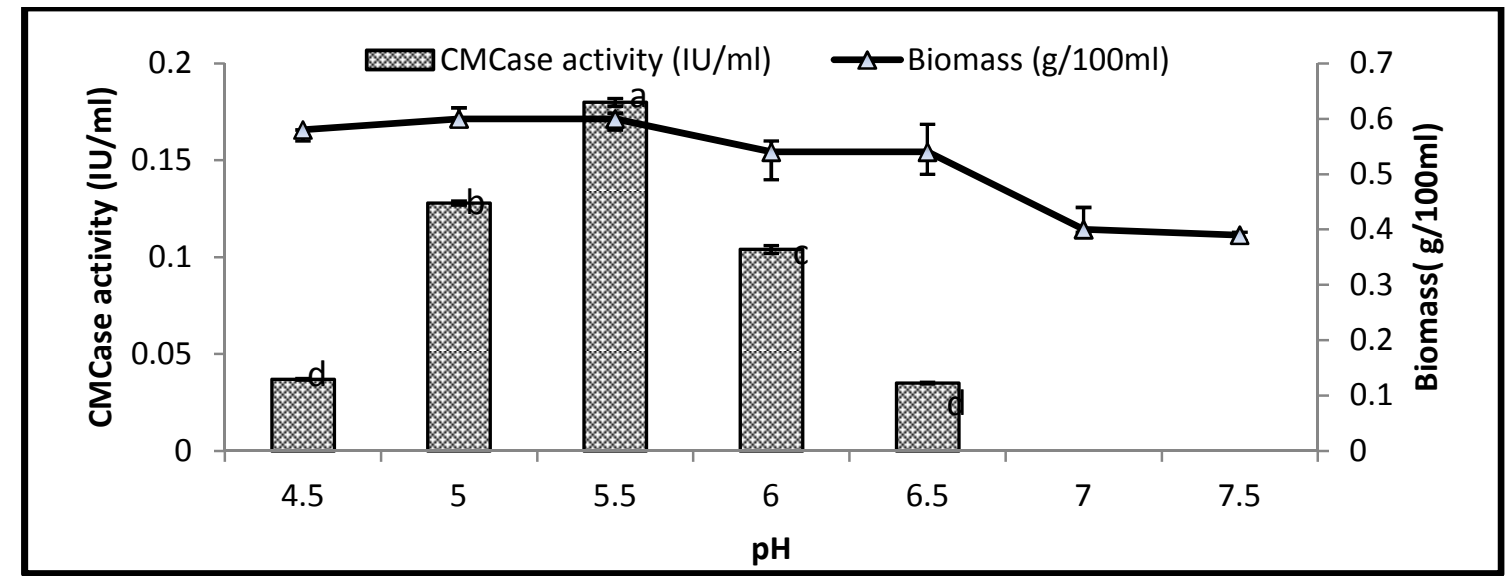

Fig.-6: Effect of pH on Biomass and CMCase production by A. flavus. Bars with Different Alphabets exhibit Statistically Significant Difference $(\mathrm{p}<0.05)$

The results were in agreement with Ahmad et al. ${ }^{38}$ and Srilakshmi et al. ${ }^{40}$ who reported maximal CMCase production at $\mathrm{pH}$ 5.5. However, several studies indicated acidic $\mathrm{pH}$ as an optimal $\mathrm{pH}$ for cellulase production. Mrudula and Murugammal $^{34}$ reported $\mathrm{pH} 6$ as an optimal $\mathrm{pH}$ for the production of 
RASĀYAN J. Chem.

Vol. 13 | No. 1 |64 - 84| January - March | 2020

extracellular cellulase using A. niger. Similar observations were also made by Pandit and Maheshwari ${ }^{41}$ and Prassana et al. ${ }^{12}$ who reported the highest CMCase activity at $\mathrm{pH} 5$ using Pleurotus sajor-caju and Penicillum sp. using SSF and SmF respectively.

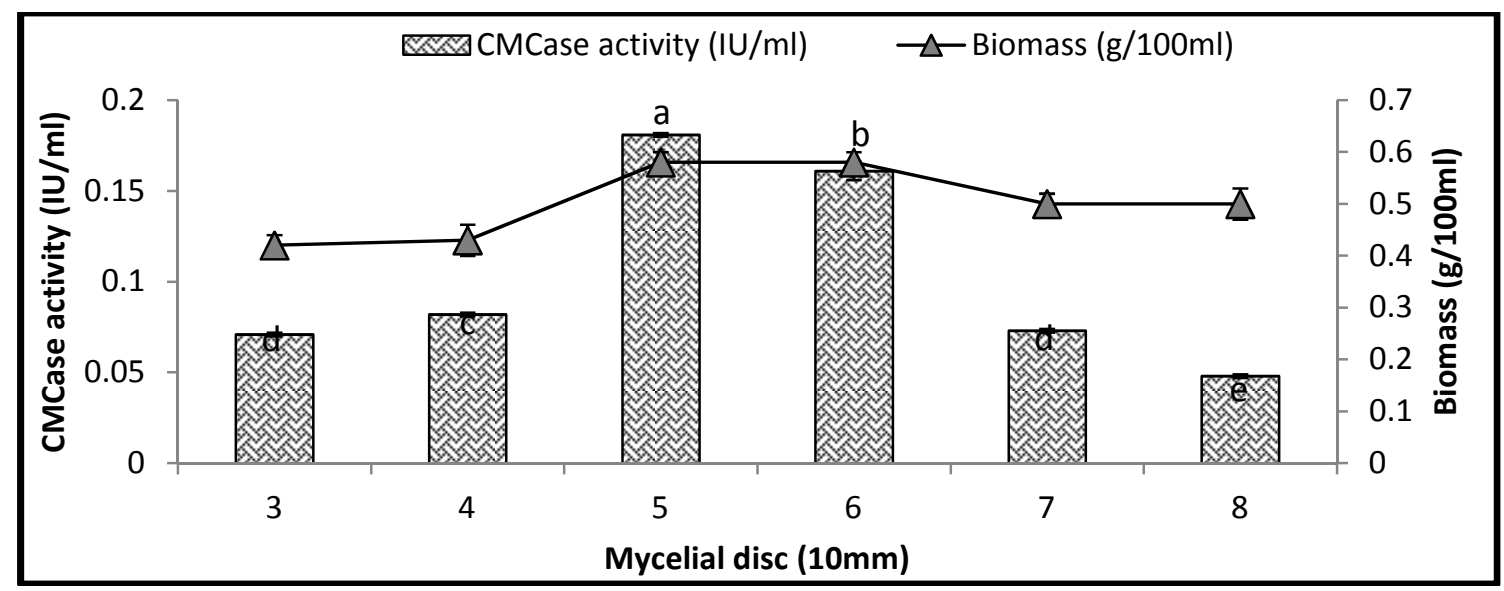

Fig.- 7: Effect of Inoculum Size on Biomass and CMCase Production by A. flavus. Bars with Different Alphabets exhibits Statistically Significant Difference $(\mathrm{p}<0.05)$

\section{Effect of Inoculum Size}

The amount of fungal inoculum has a strong impact on cellulase production. In the present study varying number of $10 \mathrm{~mm}$ mycelial disc was inoculated in the production medium. The production of CMCase and biomass was maximal after inoculation of 5 mycelial discs (Figure 7). However, biomass increased with an increase in inoculum size and remained stable thereafter. One way ANOVA followed by post hoc Duncan's test revealed significant differences in CMCase activity for different inoculum sizes $(\mathrm{F}=370.537 ; \mathrm{p}<0.001)$. Inoculum size beyond optimal conditions declined the enzyme activity. Comparable results were obtained from Acharya et al. ${ }^{43}$ who reported maximal production of CMCase by A.niger using 10 disc of $8 \mathrm{~mm}$ diameter per $100 \mathrm{ml}$ of production medium under shaking conditions. Saini et al. ${ }^{32}$ reported optimal CMCase production with two discs of Trichoderma reesei (NCIM 992) per gram of substrate. In another study Srilakshmi et al. ${ }^{40}$ reported the highest CMCase activity when $2.0 \times 10^{6} \mathrm{ml}$ inoculum volume of Purpureocillium lilacinum was utilized. It is hypothesized that lower concentration of conidial cells would take extended time period to proliferate hence are inadequate for overall utilization of substrate. ${ }^{43}$ However, increase in inoculum level beyond optimum levels could result in increased fungal biomass which will lead to rapid nutrient exhaustion causing imbalance and interference in utilizing oxygen leading to assemblage of cells and their autolysis hence, reduced cellulase biosynthesis. ${ }^{9,} 35,32$

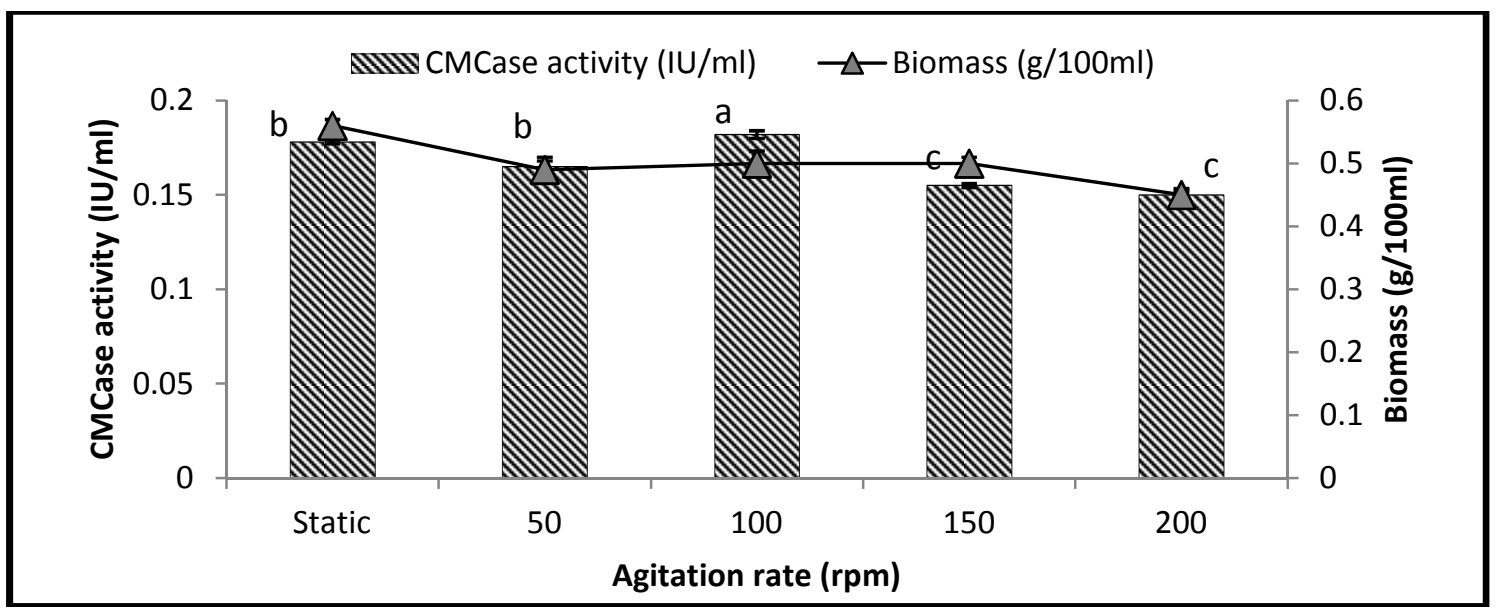

Fig.-8: Effect of Agitation Rate on Biomass and CMCase production by A. flavus. Data presented as Mean \pm SE of Duplicates. Bars with Different Alphabets exhibit Statistically Significant Difference $(p<0.05)$ 
RASĀYAN J. Chem.

Vol. 13 | No. 1 |64 - 84| January - March | 2020

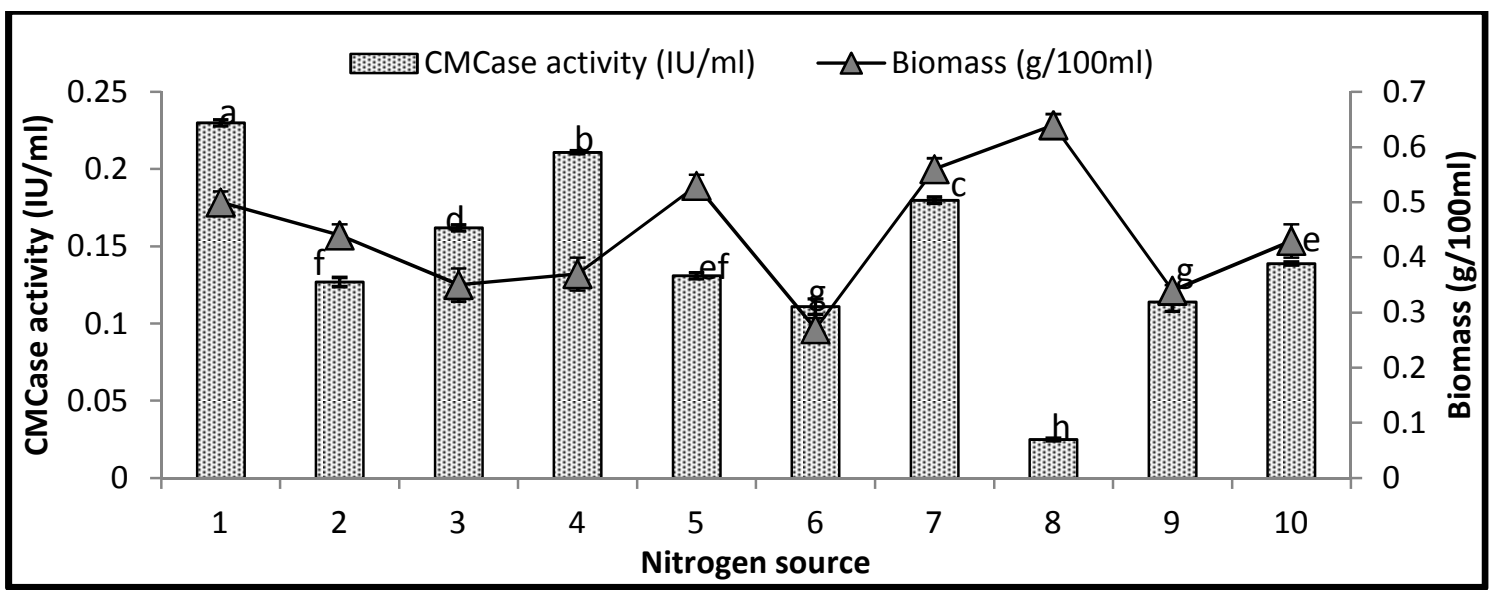

Fig.-9a: Effect of Different Nitrogen Sources on Biomass and CMCase production by A. flavus. 1. Ammonium Chloride, 2. Ammonium Sulphate, 3. L-Asparagine, 4. Meat Extract, 5. Peptone, 6. Potassium Nitrate, 7.Sodium

Nitrate (Control), 8. Tryptone, 9. Urea, 10. Yeast Extract. Bars with Different Alphabets exhibit Statistically Significant Difference $(\mathrm{p}<0.05)$

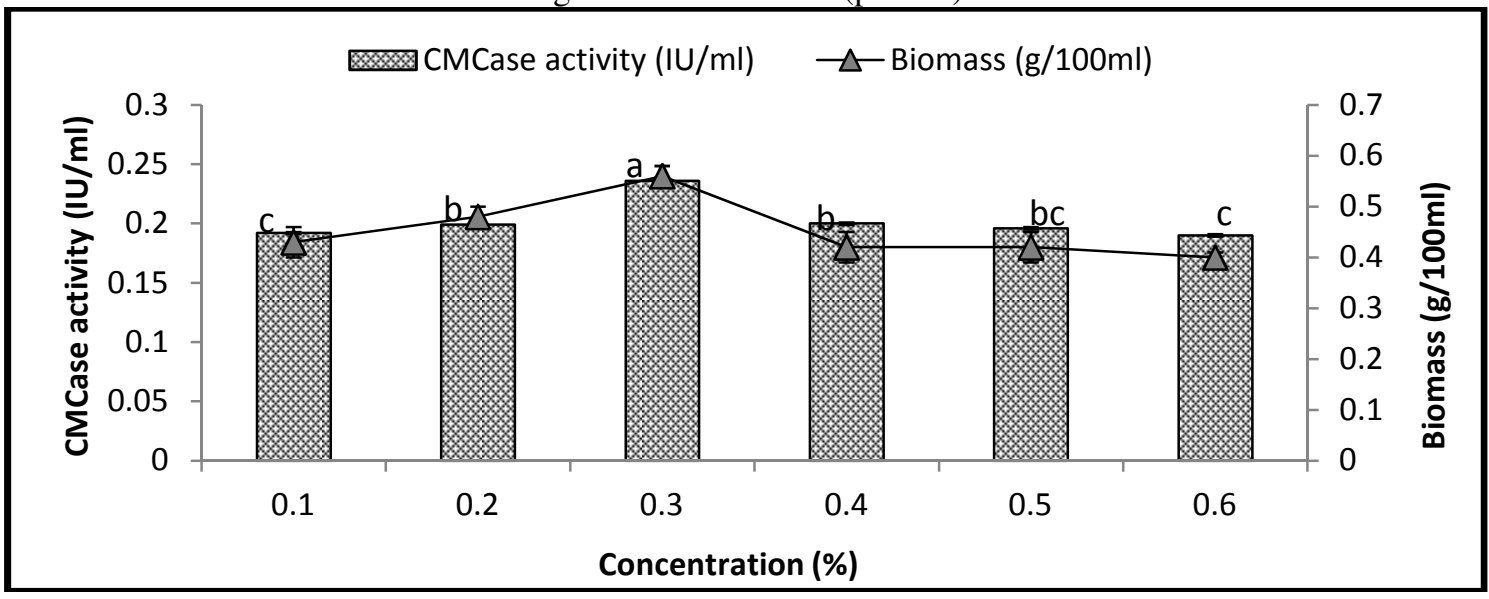

Fig.- 9b: Effect of Ammonium Chloride Concentration on Biomass and CMCase Production by A. flavus. Bars with Different Alphabets exhibit Statistically Significant Difference $(\mathrm{p}<0.05)$

\section{Effect of Agitation Rate}

The agitation rate plays an important role in increasing dissolved oxygen of the medium as well as consistent dispersal of nutrients and catabolites. ${ }^{44}$ In the present study optimal rotational speed for maximal CMCase production by A. flavus was recorded at $100 \mathrm{rpm}$. However, no noticeable variation was observed between stationary and shaking conditions. Although the highest enzymic activity recorded at $100 \mathrm{rpm}$ was $0.188 \mathrm{IU} / \mathrm{ml}$ with biomass $0.50 \mathrm{~g} / 100 \mathrm{ml}$. A statistically significant difference $\mathrm{p}<0.001$ in CMCase production was recorded between different agitation rates by $A$. flavus $(\mathrm{F}=30.884)$. No significant variation was observed in biomass at different agitation rates (Figure 8). However, increased rotational speed resulted in decreased enzyme activity, which may occur due to shear stress resulting in mycelial damage. ${ }^{45}$ The results were in agreement with Khan and Husaini ${ }^{47}$ and Sujatha et al. ${ }^{48}$ who reported maximal CMCase production at $100 \mathrm{rpm}$ using Bacillus amyloliqueficans UMAS 1002 isolated from sago pith waste and thermophilic strain of Scytalidium thermophilum SKESMBKU01 isolated from thermogenic habitats, respectively. The literature reveals differences in optimal rotational speed with respect to different microbial strains. A. terrus DSM 826 produced maximum CMCase production at 150 rpm using rice straw and sugarcane baggase. ${ }^{44}$ While, Micrococcus sp. showed enhanced CMCase production at $50 \mathrm{rpm}$ under submerged fermentation. ${ }^{48}$

\section{Effect of Nitrogen Source and Its Concentration}

Suitable nitrogen source and its appropriate concentration is an important process parameter known for inducing cellulase production in microorganisms. In the present study different nitrogen source viz. 
ammonium chloride ammonium sulphate, L-asparagine, meat extract, peptone, potassium nitrate, tryptone, urea and yeast extract were added into the $\mathrm{mCD}$ medium replacing sodium nitrate to study the effect. The study revealed ammonium chloride as the best nitrogen source for enhancing the cellulase activity i.e. $0.230 \mathrm{IU} / \mathrm{ml}$ with biomass $0.50(\mathrm{~g} / 100 \mathrm{ml})$, followed by meat extract $(0.211 \mathrm{IU} / \mathrm{ml})$ when compared with sodium nitrate (Fig.-9a, b). However, the lowest CMCase activity was observed in tryptone $(0.025 \mathrm{IU} / \mathrm{ml})$ with biomass of $0.64 \mathrm{~g} / 100 \mathrm{ml}$. Further different concentrations of ammonium chloride in the range of $0.1-0.6 \%$ were supplemented into the production medium which revealed $0.3 \%$ as suitable concentration possessing the highest CMCase production of $0.236 \mathrm{IU} / \mathrm{ml}$ and biomass 0.56 $\mathrm{g} / 100 \mathrm{ml}$.One way ANOVA and post hoc Duncan's test revealed a statistically significant difference at $\mathrm{p}<0.001$ level in CMCase activity among different nitrogen sources ( $\mathrm{F}=260.994)$ and different concentrations of ammonium chloride $(\mathrm{F}=79.727)$. The results were in accord with Abdel fateh et al. ${ }^{44}$ who reported ammonium chloride as an excellent nitrogen source for elevated enzyme production. Salts of ammonium have been reported as effective inducers for cellulase production due to the straight ingress of ammonium in protein synthesis. ${ }^{49}$ Ammonium sulphate was recorded as the suitable nitrogen source in cellulase production by A. flavus, ${ }^{50}$ while ammonium molybdate was recorded as an appropriate nitrogen source for Bacillus pumilus and T. reesei. ${ }^{51,32}$.On the contrary meat extract and tryptone enhanced CMCase production in Streptomyces sp. BRC1 and yeast extract in case of Streptomyces sp. BRC2 ${ }^{37}$. However, El-Hadi et al. ${ }^{9}$ reported peptone as an appropriate nitrogen source for maximum CMCase production.

\section{Effect of Substrate Concentration}

Optimum concentration of CMC plays an imperative role in enhancing CMCase production. The highest CMCase activity and biomass were recorded with $1.5 \%$ CMC i.e. $0.318 \mathrm{IU} / \mathrm{ml}$ and $0.79 \mathrm{~g} / 100 \mathrm{ml}$ when compared with control (1\%). One way ANOVA followed by Duncan's test revealed a statistically significant difference at $\mathrm{p}<0.001$ in CMCase activity due to different CMC concentrations by A. flavus $(\mathrm{F}=1146.344)$. There was a considerable increase in CMCase production and cell biomass with increasing concentration of CMC (Fig.-10) however, it declined when concentration reached the maximum. This is perhaps due to an increase in medium viscosity leading to a low supply of oxygen and deceleration of cell division which ultimately affects the metabolism of cells and cellulase biosynthesis. Comparable results were reported by Jyotsna et al. ${ }^{52}$ and $\mathrm{Nisha}^{53}$ who recorded $1.5 \%$ CMC optimal for CMCase production in Streptomyces albunducs and Micrococcus sp, respectively. In contrast, Gautam et al. ${ }^{33}$ reported $1 \%$ CMC as an optimal concentration for CMCase production by A .niger.

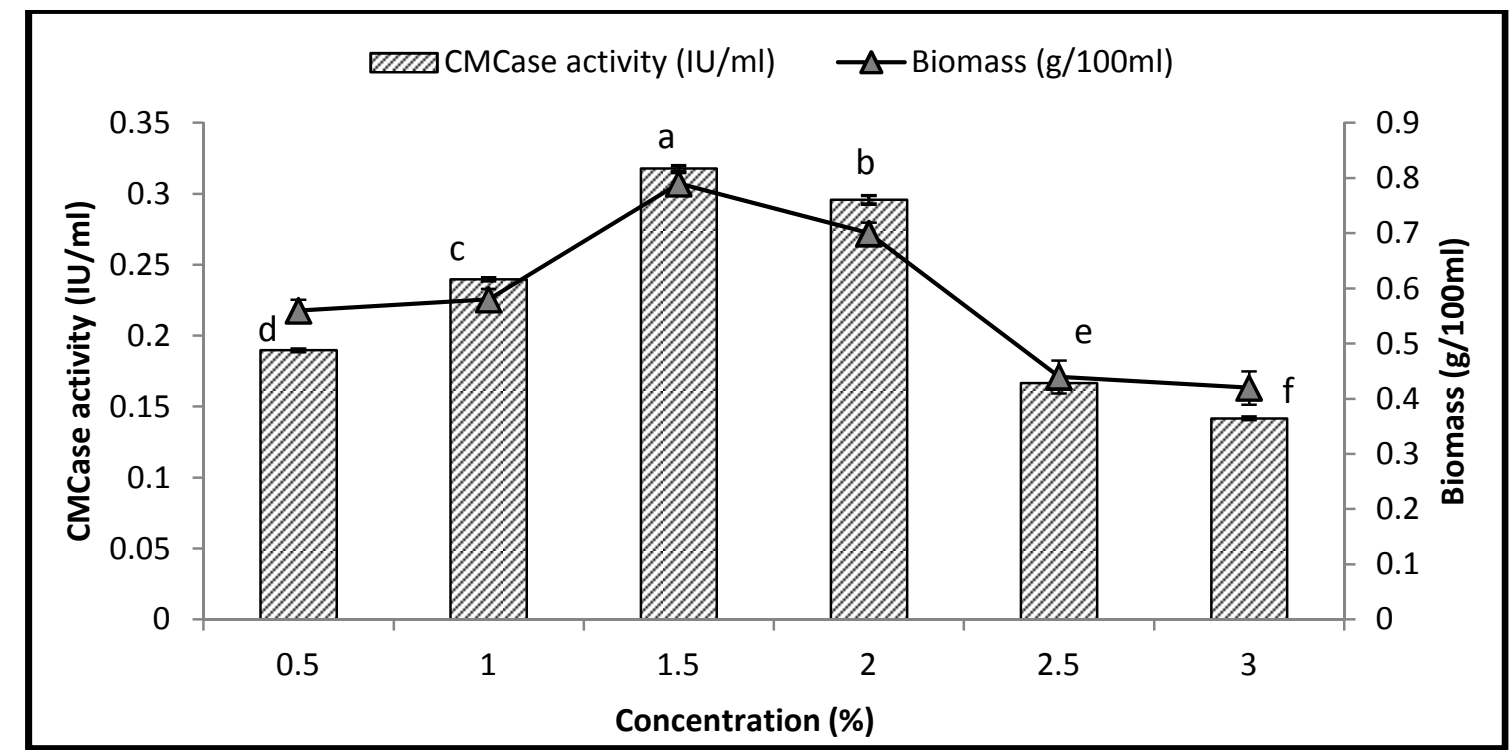

Fig.- 10: Effect of CMC Concentration on Biomass and CMCase production by A. flavus. Bars with Different Alphabets exhibits Statistically Significant Difference $(\mathrm{p}<0.05)$ 
RASĀYAN J. Chem.

Vol. 13 | No. 1 |64 - 84| January - March | 2020

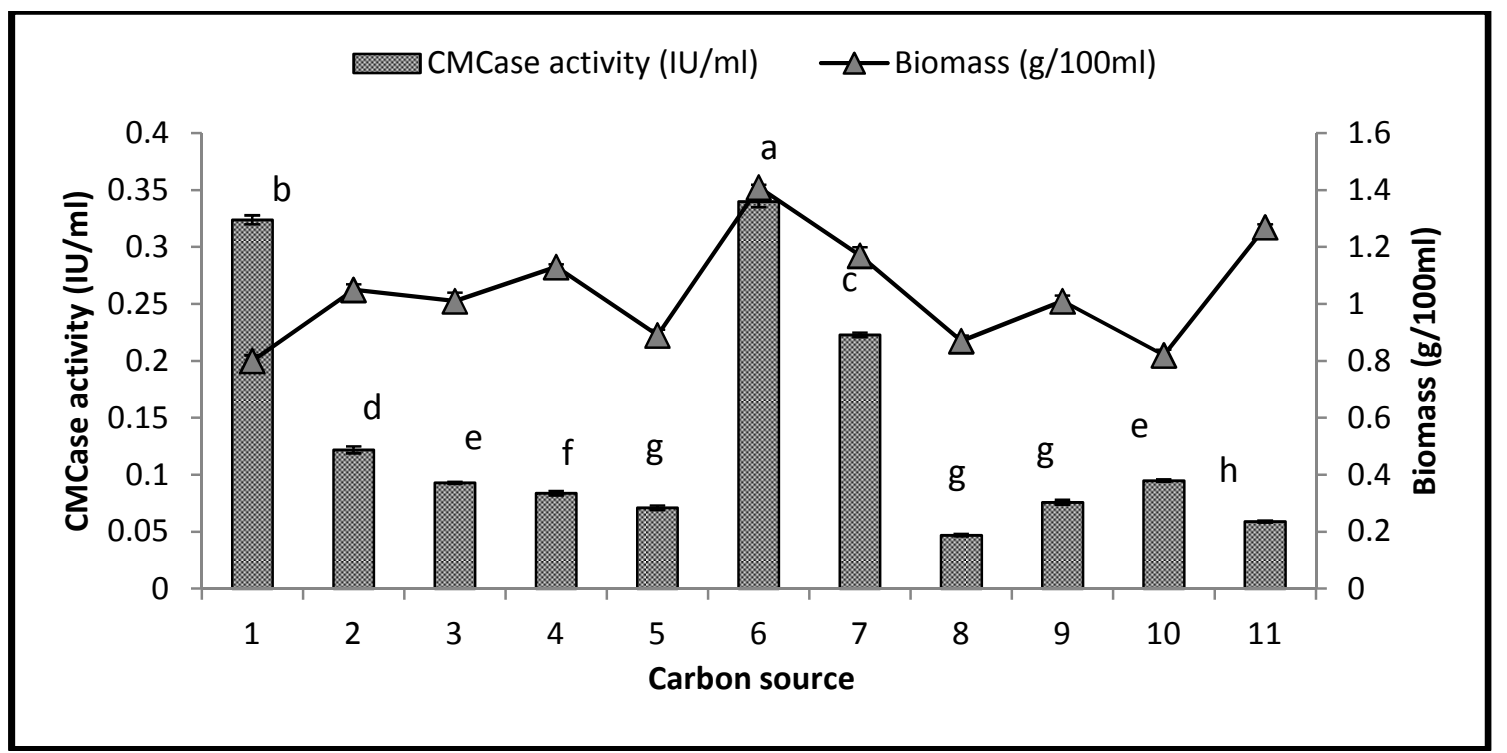

Fig.-11a: Effect of Different Carbon Sources on Biomass and CMCase Production by A. flavus. 1. Control, 2. Glucose, 3. Fructose, 4. Maltose, 5. Sucrose, 6. Avicel, 7. Cellobiose, 8. Inositol , 9. Sorbitol, 10. Inulin, 11. Starch. Bars with Different Alphabets exhibit a Statistically Significant Difference $(\mathrm{p}<0.05)$

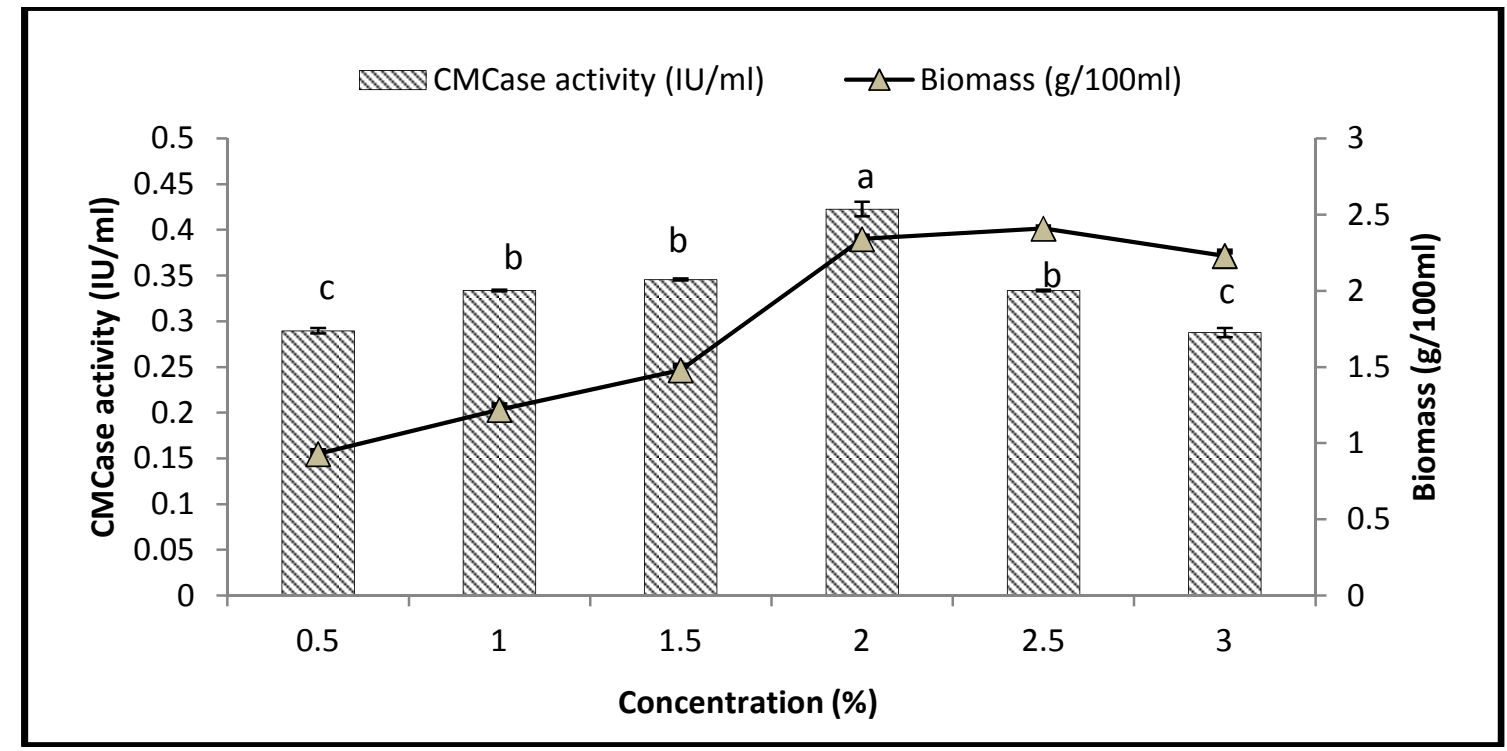

Fig.-11b: Effect of Avicel Concentration on Biomass and CMCase production by A. flavus. Data presented as mean \pm SE of Duplicates. Bar Graphs with Different Letter show Significant Difference $(\mathrm{p}<0.05)$

\section{Effect of Supplementary Carbon Source}

Carboxy methyl cellulose as a substrate plays a significant role in inducing CMCase production and fungal biomass. However, the production can be further improved in the presence of additional carbon sources $^{54}$. Therefore, the effect of different supplementary carbon sources at a concentration of $1.5 \%$ along with CMC (1.5\%) was analyzed on the enzyme production. The addition of avicel along with CMC was found to be the most potential inducer for enhanced CMCase production $(0.340 \mathrm{IU} / \mathrm{ml})$. Alternatively, all other additional carbon sources significantly repressed CMCase production. The highest biomass production was supported by avicel $(1.41 \mathrm{~g} / 100 \mathrm{ml})$ followed by starch and cellobiose. The results corroborated with Levin and Forchiassin ${ }^{55}$ who suggested cellobiose and crystalline cellulose as inducers of CMCase production by Tramates trogii. Niranjane et al ${ }^{56}$ reported CMC and avicel as strong inducers in cellulase biosynthesis for Phlebia gigantea. Cellulose along with carboxy methyl cellulose also exhibited higher cellulase yield for Streptomyces sp. and A. niger respectively ${ }^{37,33}$. The effect of avicel at 
different concentrations ranging from $0.5-3.0 \%$ for enhanced enzyme synthesis indicated that $2 \%$ avicel along with $1.5 \% \mathrm{CMC}$ supported maximal CMCase production $(0.423 \mathrm{IU} / \mathrm{ml})$. However, biomass production was highest at $2.5 \%(2.41 \mathrm{~g} / 100 \mathrm{ml})$ and lowest at $0.5 \%$ of avicel (Fig.-11a, b). One way ANOVA analysis followed by Duncan's multiple range test specified a statistically significant difference at $\mathrm{p}<0.001$ in CMCase activity for different carbon sources $(\mathrm{F}=1382.218)$ and different concentrations of avicel $(\mathrm{F}=123.743)$. Concentrations beyond optimum levels declined CMCase activity. This may be due to aggregation of soluble sugars leading to catabolite repression. On the contrary, studies also reported lactose as a good inducer for CMCase production in both liquid and solid-state fermentation. ${ }^{34}$

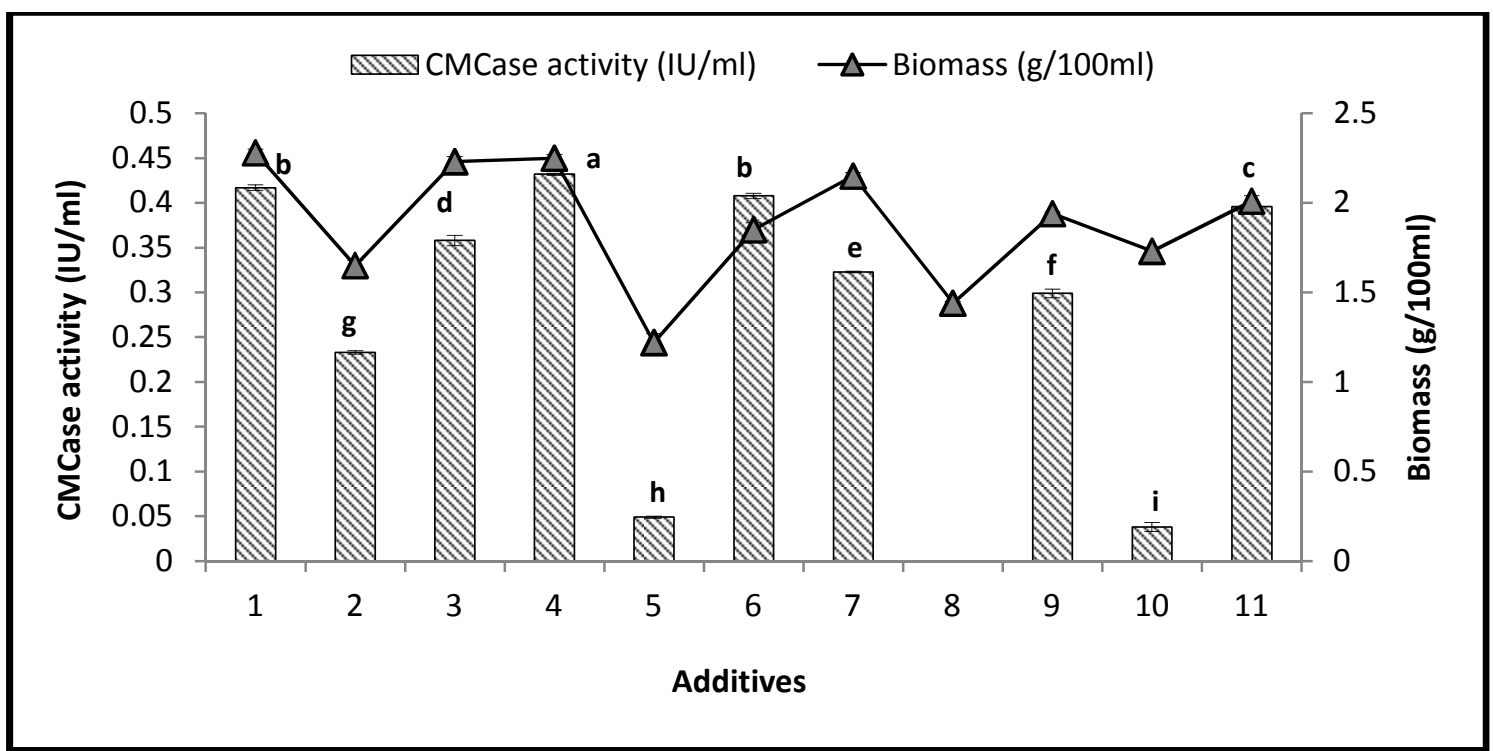

Fig.-12: Effect of Additives on Biomass and CMCase Production by A. flavus. 1. Control, 2. Tween 20, 3. Tween 80, 4. Sodium deoxycholate, 5. Clove Oil, 6. Thiamine, 7. Pyridoxine, 8. Nicotinic acid, 9. Zinc Sulphate, 10.

Cobalt Chloride, 11. Manganese Chloride. Bars with Different Alphabets exhibits Statistically Significant

\section{Effect of Additives and Metal Ions}

Difference $(\mathrm{p}<0.05)$

Apart from physical and nutritional parameters, different additives viz. surfactants (clove oil, sodium deoxycholate, Tween 20 and Tween 80), vitamins (nicotinic acid, pyridoxine and thiamine) and metal salts (cobalt chloride, manganese chloride, zinc sulphate) also exhibited stimulatory effect on enzyme production by A. flavus. As presented in Fig.-12, CMCase activity increased significantly in the presence of sodium deoxycholate $(0.432 \mathrm{IU} / \mathrm{ml})$ and biomass of $2.25 \mathrm{~g} / 100 \mathrm{ml}$ was recorded. One way ANOVA followed by Duncan's test revealed a statistically significant difference at $\mathrm{p}<0.001$ in CMCase activity by A. flavus $(\mathrm{F}=1884.785)$ due to different additives. On the contrary CMCase activity declined after the incorporation of clove oil and cobalt chloride and no activity was recorded in presence of nicotinic acid. The biomass also did not vary significantly vis-á-vis control. The above results were in accord with Chellapandi et al. ${ }^{37}$, who reported Tween 80 and sodium deoxycholate exhibiting a stimulatory effect on Streptomyces on CMCase synthesis. Abdel fateh et al. ${ }^{44}$ and Prassanna et al. ${ }^{12}$ also reported surfactants as best inducers of CMCase production because of their ability to increase cell membrane permeability as well as membrane transport leading to release of extracellular enzymes

\section{CONCLUSION}

The present investigation was oriented towards the assessment of fungal diversity and cellulolytic potential of fungal isolates from three different textile waste dumping site-s and optimization of process parameters to obtain the maximum yield of CMCase under submerged fermentation. The isolation was carried out in four different media viz. Czapek-Dox agar, malt extract agar, potato dextrose agar and Sabourauds agar for detecting the diverse fungal population. 88 fungal cultures were obtained out of which 78 isolates belonged to anamorphic ascomycetes, five belonged to zygomycetes and five isolates 
were sterile mycelia. Aspergillus proved to be the most frequently occurring genera. Aspergillus flavus Spere NFCCI-4154 was further selected as a potent cellulase producer for the optimization of CMCase production. Many reports have demonstrated improvement in enzyme production by providing elegant combinations of suitable process parameters. The parameters exhibited a remarkable effect on CMCase biosynthesis. Optimum physical and nutritional parameter recorded were incubation period of eight days, $28^{\circ} \mathrm{C}$ incubation temperature, initial $\mathrm{pH} 5.50$, inoculum size five mycelial disc of $10 \mathrm{~mm}$ diameter and agitation rate of $100 \mathrm{rpm}$ with ammonium chloride $(0.3 \%)$ as best nitrogen source, $1.5 \%$ carboxy methyl cellulose as a primary substrate with additional carbon source (2\%) avicel and $0.04 \%$ sodium deoxycholate as best additive for enhanced CMCase production. The current study incorporated preliminary work to test the potential fungal isolate for the production of CMCase. However, this study can be further extended for the production of cellulolytic enzymes via solid-state fermentation so that high titers of cellulases could be produced at low cost besides this co-culturing different fungal strains with suitable bio-reactor can also lead to enhanced production of enzyme. Studies from the fungi may supplement the need for enzymes in textile industries where they are exploited for bio stoning and bio finishing of fabrics as well as can be also used for recycling textile waste ultimately leading to decreased environmental pollution.

\section{ACKNOWLEDGMENT}

Grateful thanks are due to the head, School of Life Science, Pt. Ravishankar Shukla University for providing the research facility. The grants received from DST-FIST and UGC-DRS-SAP by the School is also duly acknowledged. The authors are grateful to the National Fungal Culture Collection, India for molecular characterization of fungal isolate.

\section{REFERENCES}

1. A. Jeihanipour and M.J. Taherzadeh, Bioresource Technology, 100, 1007(2009), DOI: 10.1016/j.biortech.2008.07.020.

2. E. Hasanzadeh, S. Mirmohamadsadeghi and K. Karimi, Fuel, 218, 41(2018), DOI: $10.1016 /$ j.fuel.2018.01.035.

3. S. Sadhu, P.K. Ghosh, G. Aditya and T.K. Maiti, Journal of King Saud University-Science, 26, 323(2014), DOI:10.1016/j.jksus.2014.06.001.

4. P. Jampala, S. Tadikamalla, M. Preethi, S. Ramanujam and K.B. Uppuluri, 3 Biotech, 7, 14 (2017), DOI: $10.1007 / \mathrm{s} 13205-017-0607-y$.

5. P. Mokrejs, D. Janacova, K. Kolomazník and P. Svoboda, Rasayan Journal of Chemistry, 4, 180 (2011).

6. S. Yang, B. Yang, C. Duan, D. A. Fuller, X. Wang, S. P. Chowdhury and Y. Ni, Bioresource Technology,281, 440(2019), DOI: 10.1016/j.biortech.2019.02.132

7. M.K. Bhat, Biotechnology Advances, 18, 355(2000)

8. M. Imran, Z. Anwar, M. Irshad, A. Javid, A. Hussain and S. Ali, Biocatalysis and Agricultural Biotechnology, 12, 191(2017), DOI: 10.1016/j.bcab.2017.10.005.

9. A.A. El-Hadi, S.A. El-Nour, A. Hammad, Z. Kamel and M.J. Anwar, Radiation Research and Applied Science, 7, 23 (2014), DOI: 10.1016/j.jrras.2013.11.003.

10. S.A. Jabasingh and C. ValliNachiyar, World Journal of Microbiology and Biotechnology, 27, 85 (2011), DOI: $10.1007 / \mathrm{s} 11274-010-0431-6$.

11. K. Matkar, D. Chapla, J. Divecha, A. Nighojkar and D. Madamwar, International Biodeterioration and Biodegradation, 78, 24 (2013), DOI: 10.1016/j.ibiod.2012.12.002

12. H.N. Prasanna, G. Ramanjaneyulu and B.R. Reddy, 3 Biotech, 6, 1(2016), DOI: 10.1007/s13205016-0483-x.

13. M. Sohail, A. Ahmad and S.A. Khan, 3 Biotech, 6, 103(2016), DOI: 10.1007/s13205-016-0420-z.

14. S.M. Al-Garni, S. Kabli, F. Al-Shehrei and Z. Al-Ganawi, Journal of King Abdulaziz University, Science, 19, 93 (2007).

15. M. V. B Rao, E. S. Reddy, V. Prasanthi and M. Sivanadh, Rasayan Journal of Chemistry, 1, 515 (2008). 
RASĀYAN J. Chem.

Vol. 13 | No. 1 |64 - 84| January - March | 2020

16. R.C. Kasana, R. Salwan, H. Dhar, S. Dutt and A. Gulati, Current Microbiology, 57, 503(2008), DOI: $10.1007 / \mathrm{s} 00284-008-9276-8$.

17. C. Florencio, S. Couri and C.S. Farinas, Enzyme Research, 2012, 1(2012), DOI: $10.1155 / 2012 / 793708$

18. L. M. Legodi, D. La Grange, E. L. Van Rensburg and I. Ncube, Enzyme Research, 2019, 1 (2019), DOI: $10.1155 / 2019 / 1390890$.

19. T.M. Wood and K.M. Bhat, Methods for measuring cellulase activities. Methods in Enzymology, 160, 87 (1988), DOI: 10.1016/0076-6879(88)60109-1

20. G.L. Miller, Anaytical Chemistry, 31, 426 (1959), DOI: 10.1021/ac60147a030

21. H. L. Barnett and B.B. Hunter, Illustrated Genera of Imperfect Fungi, Burgess Publishing Co, Minneapolis, p. 241(1972).

22. M.A. Klich, Identification of Common Aspergillus species. Central bureau voor Schimmelcultures, Utrecht, Netherlands, p. 116 (2002).

23. K. Kavkler, N. Gunde-Cimerman, P. Zalar and A. Demšar, International Biodeterioration and Biodegradation, 97, 51 (2015), DOI:10.1016/j.ibiod.2014.09.020

24. P.N. Herculano, D.M.M. Lima, M.J.S. Fernandes, R.P. Neves, C.M. Souza-Motta and A.L.F. Porto, Current Microbiology, 62, 1416 (2011), DOI: 10.1007/s00284-011-9879-3.

25. S. Jahangeer, N. Khan, S. Jahangeer, M. Sohail, S. Shahzad, A. Ahmad and S.A. Khan, Pakistan Journal Botany, 37, 739 (2005)

26. N. Saitou and M. Nei, Molecular Biology and Evolution, 4, 406 (1987), DOI: 10.1093/oxfordjournals.molbev.a040454.

27. K. Tamura, M. Nei and S. Kumar, Proceedings of National Academy Science USA, 101, 11030 (2004), DOI:10.1073/pnas.0404206101.

28. S. Kumar, G. Stecher and K. Tamura, Molecular Biology and Evolution, 33, 1870 (2016), DOI:10.1093/molbev/msw054.

29. S.V. Nochur, M.F. Roberts and A.L. Demain, Biotechnology Letters , 15, 641 (1993).

30. H.H. Azzaz, H. A. Murad, A. M. Kholif, M. A. Hanfy and M. A. Gawad, Research Journal of Microbiology, 7, 23 (2012), DOI:10.3923/jm.2012.23.31.

31. V.K. Nathan, M. E. Rani, G. Rathinasamy, K. N. Dhiraviam and S.Jayavel, Springer Plus, 3, 1(2014), DOI: $10.1186 / 2193-1801-3-92$.

32. A. Saini, N.K. Aggarwal and A. Yadav, 3 Biotech, 7, 1 (2017), DOI:10.1007/s13205-014-0246-5.

33. S.P. Gautam, P.S. Bundela, A.K. Pandey, J. Khan, M.K. Awasthi and S. Sarsaiya, Biotechnology Research International, 2011, 1 (2011), DOI: 10.4061/2011/810425

34. S. Mrudula and R. Murugammal, Brazilian Journal of Microbiology, 42, 1119(2011), DOI: 10.1590/S1517-83822011000300033.

35. S. El-Nahrawy, M. Metwally, R.Y.A. El-Kodoos, E.S.B. Belal, S.A. Shabana and I.M. El-Refai, Environmental Biodiversity and Soil Security, 1, 177(2017), DOI:10.21608/jenvbs.2017.1525.1007.

36. W. Yoon, T.N. Ang, G.C. Ngoh and A.S.M. Chua, Biomass and Bioenergy, 67, 319(2014), DOI: 10.1016/j.biombioe.2014.05.013

37. P. Chellapandi and H.M. Jani, Brazilian Journal of Microbiology, 39, 122(2008), DOI: $10.1590 /$ S1517-838220080001000026.

38. S. Ahmad, A. Bashir, H. Saleem, M. Saadia and A. Jamil, Pakistan Journal of Botany, 41, 1411 (2009)

39. S. Ali, A. Sayed, R.I. Sarker and R. Alam, World Journal of Microbiology and Biotechnology, 7, 62 (1991).

40. A. Srilakshmi, D. V. R. Sai Gopal and G. Narasimha, International Journal of Pharmacy and Bioscience, 8, 157 (2017), DOI:10.22376/ijpbs.2017.8.1.b157-165.

41. N.P. Pandit and S.K. Maheshwari, Journal of Bioremediation and Biodegradation, 3, 140 (2012), DOI:10.4172/2155-6199.1000140.

42. P.B. Acharya, D.K. Acharya and H.A. Modi, African Journal of Biotechnology, 7, 4147 (2008). 


\section{RASĀYAN J. Chem.}

Vol. 13 | No. 1 |64 - 84| January - March | 2020

43. J. Singh and P. Kaur, Brazilian Archives of Biology and Technology, 55, 505(2012), DOI: 10.1590/S1516-89132012000400004

44. O. M. Abdel-Fatah, M.M. Hassan, A.M. Elshafei, B.M. Haroun, H.M. Atta and A.M. Othman, Brazilian Journal of Microbiology, 43, 1 (2012), DOI:10.1590/S1517-83822012000100001.

45. G. Rajagopalan and C. Krishnan, Journal of Chemical Technology and Biotechnology, 83, 654 (2008), DOI: $10.1002 /$ jctb.1845

46. F.A.B.A. Khan and A.A.S.A. Husaini, Biotechnology, 5, 391(2006), DOI: 10.3923/biotech.2006.391.403.

47. E. Sujatha, S. Santosh kumar and P. Shiva Krishna, Current Research in Environmental and Applied Mycology, 4, 236 (2014), DOI: 10.5943/cream/4/2/11.

48. Z. Mmango-Kaseke, K. Okaiyeto, U.U. Nwodo, L.V. Mabinya and A.I. Okoh, Sustainability, 8, 1 (2016), DOI: $10.3390 / \mathrm{su} 8111168$.

49. A. Vyas, D. Vyas and K.M. Vyas, Journal of Scientific and Industrial Research, 64, 281(2005).

50. A. Sasi, M. Ravikumar and S. Manthirikani, African Journal of Microbiology Research, 6, 4214 (2012), DOI: 10.5897/AJMR11.074.

51. T. Shankar and L. Isaiarasu, Middle-East Journal of Scientific Research, 8, 40 (2011).

52. K.P. Jyotsna, A.R. Rao and K. Devaki, Pest Management in Horticultural Ecosystems, 21, 75 (2015)

53. P. Nisha, International Journal of Pharmaceutical, Chemical and Biological Sciences, 5, 1 (2015).

54. H. Jun, T. Kieselbach and L.J. Jönsson, Microbial Cell Factories, 10, 1(2011), DOI: 10.1186/1475-2859-10-68.

55. L. Levin and F. Forchiassin, World Journal of Microbiology and Biotechnology, 14, 443 (1998), DOI: $10.1023 / \mathrm{A}: 1008885800035$.

56. A.P. Niranjane, P. Madhou and T.W. Stevenson, Enzyme and Microbial Technology, 40, 1464 (2007), DOI: $10.1016 /$ j.enzmictec.2006.10.041.

[RJC-5536/2019] 